Review

\title{
Immunomodulatory Effect of Vitamin D and Its Potential Role in the Prevention and Treatment of Type 1 Diabetes Mellitus-A Narrative Review
}

\author{
Karolina Rak* and Monika Bronkowska \\ Department of Human Nutrition, Faculty of Biotechnology and Food Science, Wrocław University of \\ Environmental and Life Sciences, ul. Chełmońskiego 37, 51-630 Wrocław, Poland; \\ monika.bronkowska@upwr.edu.pl \\ * Correspondence: karolina.rak@upwr.edu.pl; Tel.: +48-71-320-77-04
}

Received: 26 November 2018; Accepted: 21 December 2018; Published: 24 December 2018

\begin{abstract}
Type 1 diabetes mellitus is a chronic autoimmune disease associated with degeneration of pancreatic $\beta$-cells that results in an inability to produce insulin and the need for exogenous insulin administration. It is a significant global health problem as the incidence of this disorder is increasing worldwide. The causes are still poorly understood, although it certainly has genetic and environmental origins. Vitamin D formed profusely in the skin upon exposure to sunlight, as well as from dietary sources, exhibits an immunomodulatory effect based on gene transcription control. Indeed, vitamin D can downregulate mechanisms connected with adaptive immunity, induce immunological tolerance and decrease auto-aggression-related inflammation. These properties provide the basis for a preventive and therapeutic role of vitamin D. As many studies have demonstrated, appropriate supplementation with vitamin D reduces the risk of autoimmune diseases, including type 1 diabetes mellitus, and alleviates disease symptoms in patients. The aim of this narrative review is to present the molecular mechanisms for the vitamin D immunomodulatory effect as well as review human clinical studies on the use of vitamin D as adjuvant therapy in type 1 diabetes mellitus.
\end{abstract}

Keywords: vitamin D; calcitriol; immunomodulatory effect; type 1 diabetes mellitus

\section{Type 1 Diabetes Mellitus-A Global Public Health Emergency}

Type 1 diabetes mellitus (T1DM) is a chronic autoimmune disease characterised by degeneration of pancreatic $\beta$-cells. This action results in the inability to produce insulin and need for exogenous insulin administration. T1DM is accompanied by auto-aggression-induced inflammation. The cause of this disease remains unknown; however, there are genetic factors that increase susceptibility to the disease as well as environmental triggers [1,2]. It appears suddenly and occurs at any age, but particularly in childhood [3].

The prevalence of all types of diabetes is increasing worldwide and becoming a serious global public health problem. In 2014, 422 million people around the world suffered from diabetes, compared to 108 million in 1980. During this time, the incidence of diabetes increased from 4.7 to $8.5 \%$ in the adult population [4]. Between 5 to $10 \%$ of diabetes cases are T1DM. The prevalence of T1DM is also increasing by approximately $3 \%$ every year. Currently, there are 542,000 children under 14 years old with T1DM, most of whom reside in the United States, India, Brazil and China [5].

Undiagnosed or untreated diabetes of all types, including T1DM, can cause life-changing and life-threatening health complications in many organs. Chronic elevated blood glucose can lead to heart attack, stroke, nerve damage, vision loss, kidney failure or leg amputation [4]. Moreover, 
patients with diabetes very often have to be treated for hypertension, dyslipidemia, microalbuminuria or nephropathy [6]. Finally, diabetic complications result in premature death, estimated in 2012 at 1.5 million caused directly by diabetes and an additional 2.2 million caused indirectly by higher-than-optimal blood glucose [4].

Diabetes and its complications bring economic expenditures from patients and their families and the national healthcare system. These costs are connected with hospital and outpatient care, insulin and other essential medicines, loss of productivity, loss of work and wages and long-term national financial support. In most countries, $5-20 \%$ of healthcare expenditures are spent on diabetes and diabetes-related health consequences [4,5]. This fact clearly suggests that this disease is a significant challenge for healthcare systems and raises the need to search for low-cost adjuvant therapies for diabetic patients.

\section{Genetic and Environmental Risk Factors for T1DM}

T1DM is the final consequence of $\beta$-cell autoimmunity (islet autoimmunity, IA). During the first stage, autoantibodies against insulin and/or glutamic acid decarboxylase occur. Next, additional autoantibodies against islet antigen-2 or zinc transporter-8 appear [7]. The persistent presence of at least two types of $\beta$-cell autoantibodies results in irreversible IA progression to T1DM, and in 70\% of IA-positive individuals, diabetes onset appears within the next 10 years [8].

The primary risk factor for IA (and subsequently T1DM) is genetic in origin as it occurs mainly in individuals with specific haplotypes of human leukocyte antigen that are involved in regulation of immune responses and recognition of self versus non-self cells: HLA-DR3-DQ2 or HLA-DR4-DQ8 [7]. Inheritance of these HLA alleles is responsible for over half of the overall T1DM genetic risk [9]. Genetic susceptibility only predisposes an individual to diabetes development, and environmental trigger(s) is/are necessary for IA and subsequent T1DM onset [10]. There is myriad evidence that supports the genetic-environmental origin of T1DM. The increasing prevalence of T1DM over the past few decades cannot result from genetic factors alone since genetic changes need much more time to appear [11]. Moreover, there is a substantial difference in T1DM incidence among countries characterised by very similar distribution and frequency of HLA genes that predispose autoimmunity [12]. T1DM incidence also varies significantly between populations with similar racial and ethnic backgrounds [13] as well as in individuals who are genetically close but separated by socioeconomic borders [14]. Further, a similar T1DM risk is commonly observed in migrants and native inhabitants despite the obvious genetic differences [15]. Finally, there is only evidence for partial T1DM genetic determination from studies that involve monozygotic twins [16].

Microbial and dietary triggers are among the environmental factors that might contribute to islet autoantibodies and consequently diabetes [10]. Both animal models and human studies suggest viral infections, especially caused by enteroviruses, are a potential trigger for T1DM [17-22]. Moreover, the intestinal commensal microbiota appear to be a potential modulator of T1DM risk since the composition of gut and fecal microorganisms is different in children with IA/T1DM compared to healthy controls $[23,24]$. Lower microbial diversity was suggested to increase the risk of progression to T1DM in IA-positive children $[23,25]$. There has been speculation about a potential association between vaccines and autoimmunity. The results of studies, however, revealed no association of vaccines with IA $[26,27]$ or T1DM [28,29]; these findings were fully supported by a recent meta-analysis that investigated 16 vaccinations [30].

Dietary factors are an important part of the discussion about potential T1DM triggers, although results from studies seem to be contradictory. A lot of studies focused on infant feeding, especially breastfeeding, and the age of introduction of specific food groups, notably cereals and cow milk. Breastfeeding has a protective role against autoimmunisation and reduced the IA risk in 5-year-old Swedish children [31]. Moreover, children who were still breastfed during cereal introduction into the infant diet had reduced risk of IA [32] and T1DM [33]. However, prospective birth cohort studies do not support findings about the protective effect of breastmilk [34-36]. Introduction too early (before 
the fourth month of life) or too late (after the sixth month of life) of any type of cereals (gluten or gluten-free) was both associated [32] and not [37] with increased IA risk. Other studies reported a significant association only with early [35] or late [38] exposure to gluten as well as no clear association with the moment of introduction of this cereal protein [36]. Interestingly, a gluten-free diet at 6-12 month of age did not reduce the incidence of IA in infants with high genetic risk [39] and did not decrease the level of autoantibodies in IA-positive children [40].

Similarly, studies present contradictory results regarding the potential impact of cow milk intake during childhood on IA and T1DM risk. Many prospective birth cohort studies [31-35] and randomised clinical trials [41] found no association between early exposure to cow milk and IA or T1DM. There are, however, results that suggest cow milk introduction in the second semester of life increases the risk of developing T1DM almost 4-fold in later life [42]. Studies that investigated the role of cow milk intake in later childhood also present mixed results. Some demonstrated an association between cow milk consumption with increased risk of IA [37,38,43] and T1DM [43-45], while others reported a decreased risk with T1DM [46]. A recent review on this issue conducted by Chia et al. concluded that A1 $\beta$-casein from cow milk may be a significant trigger for T1DM in genetically susceptible individuals. In the authors' opinion, many other factors modulate the risk, e.g., aberrant mucosal immunity, breastfeeding duration, exposure to other dietary triggers and vitamin $\mathrm{D}$ as well as timing and magnitude and/or duration of exposure to A1 $\beta$-casein [47].

Another potential dietary risk factor for IA and T1DM is high meat consumption. Ecological analysis of 37 world areas demonstrated an association between increased T1DM incidence and meat consumption, but not milk and cereal [48]. One study reported a dose-response association between meat, but no other examined food items intake in early life, and T1DM in childhood [49]. Moreover, maternal intake of red meat, especially processed meat, during lactation also apparently promotes T1DM development in the offspring [50]. $N$-nitroso compounds, preservatives commonly present in meat products, seem to be an important trigger of T1DM in children [51-53].

Vitamin D insufficiency and deficiency, as it will be detailed presented in Section 6, is a strong dietary risk factor for IA and T1DM development, especially at specific life stages. The problem of vitamin D status and T1DM risk is very complicated; it depends not only on dietary habits, supplementation intake and sunlight exposure, but also on polymorphisms in genes involved in the vitamin D metabolic pathway, including vitamin D receptor (VDR) [54-61], vitamin D binding protein (VDBP) [62-68], vitamin D 25-hydroxylase (CYP2R1) and 1 $\alpha$-hydroxylase (CYP27B1) [67,69-72].

VDR is found on the surface of almost all human cells, a distribution that enables the multidirectional impact of vitamin D. Studies on associations between VDR gene polymorphisms, namely Fok-I, Bsm-I, Apa-I and Taq-I, and T1DM susceptibility are inconsistent and inconclusive. Most of them demonstrated that Bsm-I [54-58] and Fok-I [54-56,59] increase T1DM risk. However, there is a discrepancy regarding which alleles most predispose an individual to diabetes development: B [56,57] or b $[54,55]$ and $F[55,56]$ or $\mathrm{f}[54]$. Fok-I F and Bsm-I B less commonly occur in T1DM patients compared to healthy controls [60]. Some studies indicate that Taq-I $[57,60]$ and Apa-I $[59,60]$ polymorphisms increase T1DM risk, although researchers present divergent conclusions on predisposing alleles: $\mathrm{T}$ [60] or $\mathrm{t}$ [57]. The results of a comprehensive meta-analysis conducted by Tizaoui et al. showed no association between individual VDR polymorphisms and T1DM risk, but haplotypes contributed significantly to disease susceptibility. Study characteristics (e.g., publication year, age, gender, vitamin D level and latitude) moderate the association between VDR polymorphisms and T1DM. This finding suggests that interactions of VDR polymorphisms among each other and with environmental factors contribute to T1DM pathogenesis [61]. This conclusion seems to explain the inconsistent results presented by different authors.

VDBP is the crucial systemic transporter of 1,25-dihydroxyvitamin D and is essential for its cellular endocytosis [62]. VDBP has three polymorphisms that may alter the affinity for $1,25(\mathrm{OH})_{2} \mathrm{D}$ [63] and affect the serum $1,25(\mathrm{OH})_{2} \mathrm{D}$ level [64]. Some studies report a relationship between VDBP 
polymorphisms and T1DM [65,66], although others did not support this finding [67,68]. T1DM patients, however, have a lower level of VDBP compared to healthy controls [68].

Two main enzymes are involved in the vitamin D metabolic pathway: vitamin D $25 \alpha$-hydroxylase converts vitamin $\mathrm{D}$ to $25(\mathrm{OH}) \mathrm{D}$, encoded by CYP2R1, and $1 \alpha$-hydroxylase that converts $25(\mathrm{OH}) \mathrm{D}$ to $1,25(\mathrm{OH})_{2} \mathrm{D}$, encoded by CYP27B1 [69]. There is an association among CYP2R1 and CYP27B1 polymorphisms and T1DM susceptibility in many [69-72], but not all studies [67].

Additional studies are urgently needed to clearly establish the association between polymorphisms in genes involved in the vitamin D metabolic pathway, including specific alleles, and vitamin D status. Subjects in future studies may be divided according to various alleles in the vitamin D pathway.

\section{Vitamin D-Sources and Recommendations}

Vitamin D is a fat-soluble steroid and precursor for human steroid hormones. One molecule is composed of four rings and one side chain. There are two natural sources of this vitamin: dietary (especially $\mathrm{D}_{3}$ from animal food and $\mathrm{D}_{2}$ contained in yeast and fungi) and exposure to UVB sunlight $\left(D_{3}\right)$ [73]. Sea fish and fish oils contain high vitamin $D_{3}$ levels $(7.5-25 \mu \mathrm{g} / 100 \mathrm{~g})$, although small amounts are also found in dairy products and eggs $(0.5-2.5 \mu \mathrm{g} / 100 \mathrm{~g})$. Dietary sources cover only approximately $20 \%$ of the recommended daily intake of this nutrient, while the vast majority of vitamin D circulating in the body comes from its biosynthesis in the skin upon exposure to UVB sunlight (75 $\mu \mathrm{g} / 10 \mathrm{~min}$ exposure to direct sunlight of arms and legs) [74].

The recommended daily intake of vitamin $\mathrm{D}_{3}$ (AI) developed by the Endocrine Practice Guidelines Committee, due to the global vitamin D deficiency pandemic [75], is 400-1000 IU for infants, 600-1000 IU for children and adolescents aged 1-18 years and 1500-2000 IU for adults (including pregnant and lactating women) and elders [76]. Vitamin D supplementation guidelines for Central Europe suggest slightly lower doses for infants (0-6 mo-400 IU, 7-12 mo-400-600 IU) and adults (800-2000 IU) than in USA, whereas recommendations for children and adolescents aged 1-18 years remains the same [77]. Moreover, separated recommendation regarding daily intake of vitamin D for pregnant and lactating women (1500-2000 IU) has been established [77]. The latest daily vitamin D intake recommendations for the general Polish population have been however tightened: 800-2000 IU for individuals aged 11-65 years, 2000 IU for seniors (>65-75 years), 2000-4000 IU for eldest seniors (>75 years) and $2000 \mathrm{IU}$ for pregnant and lactating women [78]. Additionally, children, adolescents and adults (1-65 years(s)) may supplement vitamin D by sunbathing with uncovered forearms and legs (without sunscreen) for at least $15 \mathrm{~min}$ between 10:00 and 15:00 from May to September. In seniors (>65 years), due to decreased efficiency of the skin synthesis, vitamin D supplementation is recommended throughout the entire year [78]. Supplementation of up to 10,000 IU vitamin D per day has been recognized as a safe and tolerable upper intake level for adults by the United States Academy of Sciences Institute of Medicine [79].

Interestingly, Carlberg and Hag, in their recent paper, propose the concept of the personal vitamin $D$ response index. They suggest that the need for vitamin D supplementation depends on vitamin D status with regards to an individual's personal vitamin $D$ response index rather than on vitamin $D$ status alone [80]. They claim that individuals can be distinguished into high, mid and low vitamin D responders by measuring vitamin-D-sensitive molecular parameters.

It is recommended to evaluate vitamin D status using the serum $25(\mathrm{OH}) \mathrm{D}$ concentration and define vitamin D deficiency as $25(\mathrm{OH}) \mathrm{D} \leq 20 \mathrm{ng} / \mathrm{mL}$ ( $\leq 50 \mathrm{nmol} / \mathrm{L})$, insufficiency as $25(\mathrm{OH}) \mathrm{D} 21-29 \mathrm{ng} / \mathrm{mL}$ (52.5-72.5 nmol/L) and sufficiency as 25(OH)D 30-100 ng/mL (75-250 nmol/L) [76].

Epidemiological studies demonstrated high prevalence of vitamin D deficiency or insufficiency for inhabitants of Europe, China, India, the Middle East and South America [81-84]. Therefore, supplementation of this vitamin [77] or vitamin D-fortified food intake [85,86] is recommended. 


\section{Vitamin D Metabolism-Formation of Bioactive Calcitriol}

Vitamin $D_{3}$ and $D_{2}$ are biologically inactive forms. They have to be properly metabolized in the skin, liver and kidneys to gain bioactivity and the ability to affect somatic cells. In the skin, 7-dehydrocholesterol is converted into pre-vitamin $\mathrm{D}_{3}$ and then into vitamin $\mathrm{D}_{3}$, which is subsequently released into the blood. Simultaneously, vitamin $\mathrm{D}_{3}$ and $\mathrm{D}_{2}$ from the diet are absorbed from the intestinal lumen into the blood. All circulating vitamin $\mathrm{D}$ goes to the liver where it is transformed into the $25(\mathrm{OH}) \mathrm{D}$ metabolite known as calcidiol. Finally, 25(OH)D goes from the liver to the kidneys and is converted into the biologically active metabolite $1,25(\mathrm{OH})_{2} \mathrm{D}$, known as calcitriol [87]. In order to assess vitamin D status, determination of serum $25(\mathrm{OH}) \mathrm{D}$, instead of $1,25(\mathrm{OH})_{2} \mathrm{D}$, is recommended in clinical practice [88]. The main reason for exclusion of $1,25(\mathrm{OH})_{2} \mathrm{D}$ as a diagnostic tool is its short half-life of 6-8 h, a fact that results in daily fluctuations in its serum concentration. Comparatively, the $25(\mathrm{OH}) \mathrm{D}$ half-life is 3 weeks. Moreover, in different disease states as well as extraordinary physiological states (e.g., pregnancy), elevated $1,25(\mathrm{OH})_{2} \mathrm{D}$ can occur despite actual vitamin D deficiency. Greater costs and difficulty in $1,25(\mathrm{OH})_{2} \mathrm{D}$ compared to $25(\mathrm{OH}) \mathrm{D}$ determination are further weaknesses [88]. The results of a recent clinical report, however, suggest that serum free and serum bioavailable $25(\mathrm{OH}) \mathrm{D}$, but not total serum $25(\mathrm{OH}) \mathrm{D}$, are the most appropriate and reliable markers for assessing vitamin $\mathrm{D}$ status [89].

\section{Favorable Immunomodulatory Effects of Calcitriol in Autoimmune Diseases}

The immunomodulatory effect of calcitriol is based on a genomic response and its ability to modify gene transcription. From the point of view of autoimmune diseases, the most important role of this vitamin D metabolite is its ability to downregulate all mechanisms connected with adaptive immunity and induce immunological tolerance as well as an anti-inflammatory effect [90]. The detailed immunomodulatory effects of $1,25(\mathrm{OH})_{2} \mathrm{D}$ on immune cells are presented in Table 1.

Table 1. Immunomodulatory effect of $1,25(\mathrm{OH})_{2} \mathrm{D}$.

\begin{tabular}{|c|c|c|}
\hline Immune Cell Type & Calcitriol-Induced Effect & References \\
\hline Macrophages & $\begin{array}{c}\downarrow \text { Pro-inflammatory IL-1 } \beta, \text { IL-6, TNF- } \alpha \\
\uparrow \text { Anti-inflammatory IL-10 } \\
\downarrow \text { Antigen presentation } \rightarrow \text { T cells anergy }\end{array}$ & [91-95] \\
\hline Dendritic cells & $\begin{array}{c}\downarrow \text { Pro-inflammatory IL-12, TNF- } \alpha \\
\uparrow \text { Anti-inflammatory IL-10, TGF- } \beta \\
\downarrow \text { DCs differentiation, maturation, activation } \rightarrow \\
\text { tolerogenic DCs } \\
\downarrow \text { Antigen presentation } \rightarrow \text { T cells anergy } \\
\uparrow \text { Treg }\end{array}$ & [96-103] \\
\hline $\mathrm{CD} 4^{+} \mathrm{T}$ cells & $\begin{array}{c}\downarrow \text { Th } 1 \text {, Th } 17, \text { Th1/Th2 } \\
\downarrow \text { Pro-inflammatory IFN- } \gamma, \text { IL-17, Il-22 } \\
\uparrow \text { Th 2, Treg } \\
\uparrow \text { Anti-inflammatory IL-4, IL-10 }\end{array}$ & [104-110] \\
\hline $\mathrm{CD}^{+} \mathrm{T}$ cells & $\begin{array}{c}\downarrow \text { Hyperactivation } \\
\downarrow \text { Pro-inflammatory IFN- } \gamma, \text { TNF- } \alpha\end{array}$ & {$[111,112]$} \\
\hline B cells & $\begin{array}{c}\uparrow \text { Anti-inflammatory IL-10 } \\
\downarrow \text { B cells proliferation, differentiation into plasma cells } \\
\downarrow \text { Formation of memory B cells } \\
\downarrow \text { Immunoglobulins, including auto-antibodies }\end{array}$ & [113-117] \\
\hline
\end{tabular}

Calcitriol enhances the maturation of monocytes into macrophages, but it simultaneously reduces their ability to present antigens to $\mathrm{T}$ cells by decreasing the expression of superficial histocompatibility complex MHC-II [91,92]. It also impairs dendritic cell (DC) maturation, which results in the formation of tolerogenic DCs with no surface MHC molecules that are thus unable to present 
antigens [95-98,101,102]. Impairment of antigen presentation by antigen-presenting cells (APCs) leads to $\mathrm{T}$ cell anergy (lack of response) that inhibits and/or impairs B cell proliferation, differentiation into plasma cells, formation of memory B cells and production of immunoglobulins, including autoantibodies [114-116]. Further, calcitriol promotes $\mathrm{CD}^{+} \mathrm{T}$ cell differentiation into Th 2 and regulatory $\mathrm{T}$ (Treg) cells and reduces Th 1 and Th 17 cell production. This change decreases the Th1/Th2 ratio [107-110]. Vitamin D also affects cytokine production. It stimulates immune cells to release anti-inflammatory cytokines, such as IL-4, IL-10 and TGF- $\beta$, and simultaneously decreases pro-inflammatory cytokine production, including IL-1 $\beta$, IL-6, IL-12, IL-17, IL-22, TNF- $\alpha$ and IFN- $\gamma[92,95,101,106,109,110,113]$.

The immunomodulatory effect of calcitriol described above, namely promoting the induction of immune tolerance and T cell anergy, impairing B cells activity and antibody production as well as reducing the inflammatory response, suggests a therapeutic potential for vitamin $D$ in autoimmune diseases (including T1DM). Vitamin D probably plays an important role in reducing the risk of autoimmune diseases and alleviates the disease course.

\section{Vitamin D Status in T1DM Patients}

Preclinical studies of vitamin D action on insulin secretion, insulin action, inflammatory processes and immune regulation, along with evidence of an increase of hypovitaminosis D worldwide, prompted several epidemiological, observational and supplementation clinical studies that investigated potential biological interactions between hypovitaminosis $\mathrm{D}$ and diabetes [118].

Numerous researchers clearly demonstrate the association between vitamin D and T1DM (Table 2). Swedish studies carried out on 459 T1DM patients aged 15-34 demonstrated that the 25(OH)D concentration at diagnosis was significantly lower compared to the control group. Additionally, diabetic men had a lower 25(OH)D level than diabetic women [119]. Australian children and adolescents with T1DM also had significantly lower serum vitamin D concentration compared to healthy individuals [120]. Similar results were reported by Daga et al. and Federico et al. in Indian and Italian, respectively, case control studies. Specifically, T1DM patients had significantly lower 25(OH)D level and higher prevalence of vitamin D deficiency compared to controls [121,122]. The results of the Bener et al. study conducted on 170 Qatari children under 16 years of age demonstrated that vitamin D deficiency occurs significantly more often in patients with T1DM than in healthy individuals [123]. A similar conclusion was presented by Rasoul et al. as they observed higher frequency of vitamin D deficiency and insufficiency in Kuwaiti children with T1DM than in their healthy peers [124]. The problem of inadequate vitamin D concentration is also common among Swiss children and adolescents with T1DM; $60.5 \%$ of 129 examined patients had vitamin D deficiency and $26.4 \%$ had vitamin D insufficiency [125]. However, Reinert-Hartwall et al. did not find a significant difference in the $25(\mathrm{OH}) \mathrm{D}$ level between $\beta$-cell autoantibody positive and negative, non-diabetic children, and vitamin D status was not associated with FOXP3 gene expression on $\mathrm{CD}^{+} \mathrm{T}$ cells responsible for Treg cell production [126].

\section{Vitamin D Status and the Risk of T1DM}

Although the problem of vitamin D deficiency in patients with T1DM is widely known, the cause and effect relationship has yet to be fully explored. It is not fully clear whether an inadequate vitamin D concentration is a T1DM trigger or a consequence of the disease. The available literature suggests both possibilities; vitamin D status is a strong environmental risk factor for T1DM as well as a consequence of physiological and behavioral changes that result from disease. The impact of vitamin D on T1DM risk appears to be dependent on the stage of life. Results regarding the association between prenatal exposure of fetus to vitamin D measured by maternal 25(OH)D level, vitamin D status or vitamin D-fortified food intake in pregnancy and T1DM risk in the offspring are inconclusive. Sørensen et al. demonstrated a significantly lower gestational 25(OH)D level in Norwegian mothers of children who developed T1DM within the first 15 years of life than in those who remained non-diabetic. This study 
also revealed a significant trend towards a higher risk for T1DM in offspring with lower gestational levels of vitamin D [127]. Moreover, the results of the D-tect study conducted by Jacobsen et al. showed a significant 1.5-to-2-fold higher risk of T1DM in males (but not females) aged up to 14 years old whose mothers did not eat vitamin D-fortified margarine during pregnancy compared to those whose mothers did eat it [128]. Miettinen et al., however, found no significant difference in 25(OH)D level and vitamin D status in pregnancy between Finnish mothers of children who developed T1DM up to the seventh year of life compared to controls [129]. Similarly, the results of a meta-analysis of observational studies conducted by Dong et al. showed no significant association between total vitamin $\mathrm{D}$ or cod liver oil intake by pregnant women and the risk of T1DM in their offspring [130]. The 25(OH)D level in newborns at birth was not associated with T1DM risk up to tenth year of life, and the difference in the 25(OH)D level at birth between T1DM cases and controls was insignificant [131]. Further studies are needed to clearly establish whether or not prenatal exposure to vitamin D affects T1DM risk in later life.

Supplementation with vitamin D in infancy, however, appears to have a more pronounced effect on the risk of T1DM than prenatal exposure to this vitamin. The results of meta-analysis conducted by Zipitis et al. that included observational studies mainly from the EURODIAB project suggests that vitamin D supplementation at this stage of life may decrease the risk of T1DM in later life [132]. The same conclusion was made by Dong et al. [130]. In both analyses, T1DM risk in individuals who received vitamin D supplementation in infancy was reduced almost 1.5-fold [130,132]. Moreover, Jacobsen et al. reported that exposure to vitamin D-fortified margarine during the first year of life (probably through breastfeeding) reduced the risk of T1DM in males (but not females) aged up to 14 years old by $2-7.5$ times [128].

Stene and Joner demonstrated, however, that the timing of vitamin $\mathrm{D}$ administration is crucial to achieve the beneficial effect. Infants supplemented with vitamin D between 7 and 12 months of age had a 1.8-fold lower T1DM risk than those supplemented from birth until 6 months of age [133]. This finding is probably due to the fact that adaptive immunity mechanisms become competent during the second 6 months of life. Thus, during the first 6 months of life, vitamin D does would have little to no regulatory effect on their action [134]. Vitamin D supplementation dosage and duration in infancy were not considered in the majority of studies included in meta-analyses mentioned above. Only Hyppönen et al. demonstrated that regular supplementation with the recommended daily vitamin D dose (2000 IU for Finnish infants) during the whole infancy period reduced the risk of T1DM (4-to-5-fold) within the first year of life compared to regular supplementation with lower doses [135].

The results of follow-up studies conducted on children at different ages suggest no association between pre-diagnostic vitamin D status and T1DM onset in later life. Although Raab et al. demonstrated a significantly lower 25(OH)D level and higher prevalence of vitamin D deficiency in German children with islet auto-antibodies (IAab-positive) compared to IAab-negative controls, they found no association between vitamin D deficiency and T1DM progression in IAab-positive children over an almost 6-year observation period [136]. There was no significant difference in pre-diagnostic 25(OH)D level between Finnish children who developed T1DM and those who remained healthy as well as no relationship between the 25(OH)D level and risk of T1DM [137]. Similarly, Simpson et al. found no significant association between pre-diagnostic vitamin D status and $25(\mathrm{OH}) \mathrm{D}$ level in US American children and risk of IA or progression to T1DM [138].

In young adults, however, vitamin D status appears to exert a clear impact on T1DM risk. A follow-up study carried out by Gorham et al. on US American military service members showed significantly lower 25(OH)D levels in individuals who during an average of 1 year developed insulin-requiring DM compared to age-matched controls. Moreover, they found a significant trend towards a higher risk of insulin-requiring DM in individuals with lower pre-diagnostic serum 25(OH)D [139]. Another study conducted with a similar group (US American active-duty military personnel) by Munger et al. supported Gorham's et al. findings, but only for non-Hispanic whites [140]. They demonstrated significantly lower T1DM risk for those individuals with a pre-diagnostic $25(\mathrm{OH}) \mathrm{D}$ 
level $\geq 100 \mathrm{nmol} / \mathrm{L}$ compared to those with a level $<75 \mathrm{nmol} / \mathrm{L}$. They also observed a significant trend towards a higher T1DM risk in individuals with lower 25(OH)D levels. Finally, there was no significant association between the 25(OH)D level and T1DM risk in non-Hispanic blacks or Hispanics [140].

The results presented above clearly demonstrate that vitamin D status can be considered an environmental risk factor of T1DM, especially at some life stages, e.g., infancy. Simultaneously, there is unequivocal evidence that the widespread problem of vitamin D deficiency in T1DM patients may be a consequence of physiological and behavioral changes that result from the disease. Thrailkill et al. reported enhanced vitamin D binding protein excretion in urine from T1DM patients, and this finding suggests that the disease-induced disrupted vitamin D metabolism can increase the risk of vitamin D deficiency in patients [141]. Moreover, reduced outdoor and sunlight exposure, as declared by T1DM patients, may also contribute to vitamin D deficiency in this group of people [120]. It can therefore be assumed that an insufficient vitamin D concentration increases the T1DM risk, which in turn exacerbates the $25(\mathrm{OH}) \mathrm{D}$ deficiency. Table 3 presents follow-up studies regarding the association between pre-diagnostic vitamin D status and T1DM risk.

\section{Vitamin D in T1DM Treatment}

Many interventional studies and randomized controlled trials established positive clinical effects in patients with T1DM. Insulin therapy supplemented with different forms of vitamin D—cholecalciferol, alfacalcidiol and calcitriol-improve the preservation of residual pancreatic $\beta$-cells function in T1DM patients [142-146]. A significantly higher level of fasting C-peptide (FCP) and/or lower needed daily insulin dose (DID) was observed in supplemented groups. Li et al. noted, however, that the positive effect occurred only in latent autoimmune diabetes of adults (LADA) patients with a diabetes duration $\leq 12$ months [144]. Moreover, Pitocco et al. showed that the decreased insulin need was only temporary (up to 6 months) [146]. Males appear to be more sensitive to alfacalcidiol, since Ataie-Jafari et al. observed a stronger increase in FCP and decrease in DID in males compared to females [145]. Mishra et al. presented a trend, although insignificant, toward a lower decline in residual pancreatic $\beta$-cell function in supplemented patients [147]. Additionally, Federico et al. demonstrated significant inhibition of auto-aggression and protective effect on pancreatic $\beta$-cells function in patients supplemented with calcidiol. Decreased reactivity of peripheral blood mononuclear cells against glutamic acid decarboxylase and pro-insulin as well as stable FCP level was observed in this group [148].

The results of interventional studies conducted by Giri et al., Dehkordi et al. and Bogdanou et al. revealed that cholecalciferol adjuvant therapy improves glycemic control in T1DM patients. A significant decrease in $\mathrm{HbA1C}$ (glycated hemoglobin) level occurred after 3 months of treatment with cholecalciferol at different doses $[143,149,150]$. This form of vitamin D also prevents micro- and macrovascular complications related to chronic elevated blood glucose in diabetic patients [150] and improves endothelial function [151].

Interventional studies and randomised controlled trials proved that insulin therapy supplemented with cholecalciferol has a protective immunological effect in both patients with recent-onset T1DM as well as those with a longer duration of diabetes. Gabbay et al. observed a significant increase in Treg cells in patients supplemented with $2000 \mathrm{IU}$ of cholecalciferol daily for 12 months [152]. A similar effect was reported by Bogdanou et al., who administrated $4000 \mathrm{IU}$ of cholecalciferol daily for 3 months to T1DM patients. An increased Treg cell percentage, however, was only observed in males [143]. Cholecalciferol not only enhances the number of Treg cells, but it also improves their suppressor function. Indeed, Treiber et al. demonstrated this vitamin $\mathrm{D}_{3}$ capacity in a randomised controlled trial [153]. After 12 months of daily $70 \mathrm{IU} / \mathrm{kg}$ cholecalciferol supplementation, the supplemented group had a significantly increased Treg cell suppressive capacity compared to the placebo group [153].

There are also studies that indicate no significant role for vitamin $\mathrm{D}$ in the treatment of T1DM patients. Bizzarri et al. and Walter et al. conducted randomised double-blinded placebo-controlled trials in recent-onset patients with T1DM. They demonstrated no protective effect of 
daily supplementation with $0.25 \mu \mathrm{g}$ calcitriol for $18-24$ months on pancreatic $\beta$-cell function $[154,155]$. Perchard et al., in their 24-month interventional study that involved one-off supplementation of 100,000 or 160,000 IU of cholecalciferol, indicated no effect on glycemic control in children with T1DM [156].

Detailed information on the interventional studies cited above are presented in Table 4, and Table 5 contains detailed information on randomised controlled trials.

It should be noted that the vitamin D response index that results from an individual molecular response to vitamin D supplementation could explain the discrepancies between studies and could be used for stratification of future study cohorts. 
Table 2. Vitamin D and type 1 diabetes mellitus: observational case-control studies.

\begin{tabular}{|c|c|c|c|c|c|}
\hline Place of Study & Cases and Controls & 25(OH)D Level at Diagnosis & Vitamin D Deficiency & Significant Findings & References \\
\hline Sweden & $\begin{array}{l}\text { Age: } 15-34 \text { y } \\
\text { Cases: } 459 \\
\text { Controls: } 208\end{array}$ & $\begin{array}{l}\text { Cases: } 82.5 \pm 1.3 \mathrm{nmol} / \mathrm{L} \\
\sigma^{7}: 77.9 \pm 1.4 ; \circ: 90.1 \pm 2.4 \mathrm{nmol} / \mathrm{L} \\
\text { Controls: } 96.7 \pm 2.0 \mathrm{nmol} / \mathrm{L}\end{array}$ & & $\begin{array}{c}\text { Significantly lower 25(OH)D } \\
\text { level in cases than in controls. } \\
\text { Significantly lower } 25(\mathrm{OH}) \mathrm{D} \text { in } \\
\text { diabetic men than women. }\end{array}$ & [119] \\
\hline Australia & $\begin{array}{l}\text { Age: pediatric } \\
\text { Cases: } 56 \\
\text { Controls: } 46\end{array}$ & $\begin{array}{c}\text { Cases: } 78.7(71.8-85.6) \mathrm{nmol} / \mathrm{L} \\
\text { Controls: } 91.4(83.5-98.7) \mathrm{nmol} / \mathrm{L}\end{array}$ & & $\begin{array}{l}\text { Significantly lower } 25(\mathrm{OH}) \mathrm{D} \\
\text { level in cases than in controls. }\end{array}$ & [120] \\
\hline India & $\begin{array}{l}\text { Age: }<25 \text { y } \\
\text { Cases: } 72 \\
\text { Controls: } 41\end{array}$ & $\begin{array}{c}\text { Cases: } 7.88 \pm 1.2 \mathrm{ng} / \mathrm{mL} \\
\text { Controls: } 16.64 \pm 7.83 \mathrm{ng} / \mathrm{mL}\end{array}$ & $\begin{array}{l}\text { Cases: } 91.1 \% \\
\text { Controls: } 58.5 \%\end{array}$ & $\begin{array}{c}\text { Significantly lower } 25(\mathrm{OH}) \mathrm{D} \\
\text { level and higher prevalence of } \\
\text { vitamin D deficiency in cases } \\
\text { than in controls. }\end{array}$ & [121] \\
\hline Italy & $\begin{array}{l}\text { Age: pediatric } \\
\text { Cases: } 82 \\
\text { Controls: } 117\end{array}$ & $\begin{array}{l}\text { Cases: } 54.4 \pm 27.3 \mathrm{nmol} / \mathrm{L} \\
\text { Controls: } 74.1 \pm 28.5 \mathrm{nmol} / \mathrm{L}\end{array}$ & $\begin{array}{l}\text { Cases: } 48.8 \% \\
\text { Controls: } 17.9 \%\end{array}$ & $\begin{array}{c}\text { Significantly lower } 25(\mathrm{OH}) \mathrm{D} \\
\text { level and higher prevalence of } \\
\text { vitamin D deficiency in cases } \\
\text { than in controls. }\end{array}$ & [122] \\
\hline Qatar & $\begin{array}{l}\text { Age: }<16 \\
\text { y Cases: } 170 \\
\text { Controls: } 170\end{array}$ & & $\begin{array}{l}\text { Cases: } 90.6 \% \\
\text { Controls: } 85.3 \%\end{array}$ & $\begin{array}{l}\text { Significantly higher prevalence of } \\
\text { vitamin D deficiency in cases } \\
\text { than in controls. }\end{array}$ & [123] \\
\hline Kuwait & $\begin{array}{l}\text { Age: pediatric } \\
\text { Cases: } 216 \\
\text { Controls: } 204\end{array}$ & & $\begin{array}{l}\text { Cases: total } 99 \% \\
\text { Deficiency: } 84 \% \\
\text { Insufficiency: } 15 \% \\
\text { Controls: total } 92 \% \\
\text { Deficiency: } 77 \% \\
\text { Insufficiency: } 15 \%\end{array}$ & $\begin{array}{l}\text { Significantly higher prevalence of } \\
\text { vitamin D deficiency and vitamin } \\
\mathrm{D} \text { (deficiency + insufficiency) in } \\
\text { cases than in controls. }\end{array}$ & [124] \\
\hline Finland & $\begin{array}{l}\text { Age: pediatric } \\
\text { Cases: } 35 \\
\text { Controls: } 80\end{array}$ & $\begin{array}{l}\text { Cases }(\beta \text {-cell Aab+): } 70.6 \pm 20.8 \mathrm{nmol} / \mathrm{L} \\
\text { Controls }(\beta \text {-cell Aab-): } 65.7 \pm 19.4 \mathrm{nmol} / \mathrm{L}\end{array}$ & & $\begin{array}{l}\text { No significant difference in } \\
25(\mathrm{OH}) \mathrm{D} \text { level in cases and } \\
\text { controls. }\end{array}$ & [126] \\
\hline
\end{tabular}

$0^{7}$-males; †-females; Aab+: autoantibodies-positive; Aab-: autoantibodies-negative. 
Table 3. Vitamin D status and the risk of type 1 diabetes mellitus: prospective cohort follow-up studies.

\begin{tabular}{|c|c|c|c|c|}
\hline Place of Study & Study Group & Clinical Findings & Conclusions & References \\
\hline Norway & $\begin{array}{l}\text { Age: } \leq 15 \text { y } \\
\text { Cases: } 109 \\
\text { Controls: } 219 \\
\text { Follow-up: } 15 \text { y }\end{array}$ & $\begin{array}{l}\text { Maternal 25(OH)D level (37 week of pregnancy): } \\
\text { Cases: } 65.8 \pm 26.5 \mathrm{nmol} / \mathrm{L} ; \text { Controls: } 73.1 \pm 27.2 \mathrm{nmol} / \mathrm{L} \\
\text { Adjusted OR of T1DM for } 25(\mathrm{OH}) \mathrm{D} \text { level }[\mathrm{nmol} / \mathrm{L}] \\
\leq 54 \text { vs }>89: 2.38(95 \% \mathrm{Cl} 1.12-5.07) \\
>54 \text { and } \leq 69 \text { vs }>89: 1.78 \text { (95\% Cl } 0.85-3.74) \\
>69 \text { and } \leq 89 \text { vs }>89: 1.35 \text { (95\% Cl } 0.63-2.89) \\
\text { P for trend (continuous): } 0.031\end{array}$ & $\begin{array}{l}\text { Significantly lower gestational } 25(\mathrm{OH}) \mathrm{D} \\
\text { level in mothers of children with T1DM } \\
\text { than in those of healthy children. } \\
\text { Significant trend toward a higher risk of } \\
\text { T1DM in the offspring with lower levels of } \\
\text { vitamin D during pregnancy. }\end{array}$ & [127] \\
\hline Finland & $\begin{array}{l}\text { Age: } \leq 7 \text { y } \\
\text { Cases: } 343 \\
\text { Controls: } 343 \\
\text { Follow-up: } 17 \text { y }\end{array}$ & $\begin{array}{c}\text { Maternal 25(OH)D level (1st trimester of pregnancy): } \\
\text { Cases: } 43.9 \pm 16.9 \mathrm{nmol} / \mathrm{L} ; \text { Controls: } 43.5 \pm 16.6 \mathrm{nmol} / \mathrm{L} \\
\text { Maternal vitamin D status }(p=0.88): \\
\text { deficiency: cases }(n=33) \text {, controls }(n=32) \\
\text { insufficiency: cases }(n=208) \text {, controls }(n=208) \\
\text { sufficiency: cases }(n=85) \text {, controls }(n=90) \\
\text { optimal: cases }(n=17) \text {, controls }(n=13)\end{array}$ & $\begin{array}{l}\text { No significant difference in maternal } \\
25(\mathrm{OH}) \mathrm{D} \text { level and vitamin } \mathrm{D} \text { status in } \\
\text { pregnancy between cases and controls. }\end{array}$ & [129] \\
\hline Italy & $\begin{array}{l}\text { Age: } \leq 10 \text { y } \\
\text { Cases: } 67 \\
\text { Controls: } 236 \\
\text { Follow-up: } 10 \mathrm{y}\end{array}$ & $\begin{array}{l}\text { Geometric mean of } 25(\mathrm{OH}) \mathrm{D} \text { level at birth: } \\
\text { Cases: } 1.42(0.80-3.00) ; \text { Controls: } 1.81(0.96-3.40) \\
\text { Adjusted OR of T1DM up to } 10 \text { y of age }(0.78 ; 95 \% \mathrm{Cl} \\
0.56-1.10) \text { for each unit increment in log vitamin D }\end{array}$ & $\begin{array}{c}\text { No association between } 25(\mathrm{OH}) \mathrm{D} \text { level at } \\
\text { birth and risk of T1DM up to } 10 \text { years } \\
\text { of age. }\end{array}$ & [131] \\
\hline Finland & $\begin{array}{c}\text { Age: } \leq 1 \mathrm{y} \\
\text { Cases: } 81 \\
\text { Controls: } 10,285 \\
\text { Follow-up: first year } \\
\text { of life }\end{array}$ & $\begin{array}{l}\text { Adjusted RR of T1DM for vitamin D supplementation: } \\
\text { regular vs no supplement. }(0.12 ; 95 \% \mathrm{Cl} 0.03-0.51) \\
\text { irregular vs no supplement. }(0.16 ; 95 \% \mathrm{Cl} 0.04-0.74) \\
\text { regular recommended dose vs regular less than } \\
\text { recommended doses }(0.22 ; 95 \% \mathrm{Cl} 0.05-0.89)\end{array}$ & $\begin{array}{l}\text { Significantly reduced risk of T1DM in } \\
\text { infants supplemented with vitamin D } \\
\text { within the first year of life. Higher } \\
\text { protective effect provided by the } \\
\text { recommended dose of vitamin D (2000 IU). }\end{array}$ & [135] \\
\hline Germany & $\begin{array}{l}\text { Age: pediatric } \\
\text { Cases: 352 IA, including } \\
\text { 244 T1DM } \\
\text { Controls: } 406 \\
\text { Follow-up: } 5.8 \text { y }\end{array}$ & $\begin{array}{c}\text { 25(OH)D level within } 2 \text { y of IAab seroconversion: } \\
\text { Cases: } 59.9 \pm 3.0 \mathrm{nmol} / \mathrm{L} \text {; Controls: } 71.9 \pm 1.5 \mathrm{nmol} / \mathrm{L} \\
\text { Vitamin D deficiency: } \\
\text { Cases: } 39.8 \% \text {; Controls: } 28.3 \% \\
\text { Cumulative incidence of T1DM at } 10 \text { y after IAab } \\
\text { seroconversion: } \\
\text { children with vitamin D deficiency: } 51.8 \% \\
\text { children with vitamin D sufficiency: } 55.4 \%\end{array}$ & $\begin{array}{l}\text { Significantly lower } 25(\mathrm{OH}) \mathrm{D} \text { level and } \\
\text { higher prevalence of vitamin D deficiency } \\
\text { in IAab-positive children than } \\
\text { IAab-negative controls. No association } \\
\text { between vitamin D deficiency and } \\
\text { progression to T1DM in } \\
\text { IAab-positive children. }\end{array}$ & [136] \\
\hline
\end{tabular}


Table 3. Cont.

\begin{tabular}{|c|c|c|c|c|}
\hline Place of Study & Study Group & Clinical Findings & Conclusions & References \\
\hline Finland & $\begin{array}{c}\text { Age: pediatric } \\
\text { Cases: } 126 \\
\text { Controls: } 126 \\
\text { Follow-up: } 4.5-6 \text { y }\end{array}$ & $\begin{array}{c}\text { Median 25(OH)D level of multiple collected samples } \\
\text { before diagnosis: } \\
\text { Cases: } 66.6 \mathrm{nmol} / \mathrm{L}(14.0-262.8) \\
\text { Controls: } 67.4 \mathrm{nmol} / \mathrm{L}(19.9-213.0) \\
\text { Correlation between 25(OH)D level and: } \\
\text { age at seroconversion to IAab-positivity }(p=0.79) \\
\text { T1DM onset }(p=0.13)\end{array}$ & $\begin{array}{l}\text { No significant difference in } 25(\mathrm{OH}) \mathrm{D} \text { level } \\
\text { between cases and controls. No association } \\
\text { between } 25(\mathrm{OH}) \mathrm{D} \text { level and risk of T1DM. }\end{array}$ & [137] \\
\hline USA & $\begin{array}{l}\text { Age: pediatric } \\
\text { Cases: } 198 \text { IA, including } \\
90 \text { T1DM } \\
\text { Controls: } 2644 \\
\text { Follow-up: } 18 \mathrm{y}\end{array}$ & $\begin{array}{l}\text { Adjusted HR of T1DM for intake of vitamin D and: } \\
\text { risk of IA }(1.13 ; 95 \% \mathrm{Cl} 0.95,1.35 ; p=0.18) \\
\text { progression to T1DM }(1.12 ; 95 \% \mathrm{Cl} 0.91,1.86 ; p=0.15) \\
\text { Adjusted HR of T1DM for 25(OH)D level and: } \\
\text { risk of IA (1.12; } 0.95 \% \mathrm{Cl} 0.88,1.43 ; p=0.36) \\
\text { progression to T1DM }(0.91 ; 95 \% \mathrm{Cl} 0.68,1.22 ; p=0.54)\end{array}$ & $\begin{array}{l}\text { No association between vitamin } \mathrm{D} \text { intake } \\
\text { and } 25(\mathrm{OH}) \mathrm{D} \text { levels throughout childhood } \\
\text { and risk of IA or progression to T1DM. }\end{array}$ & [138] \\
\hline USA & $\begin{array}{l}\text { Age: } 17-35+ \\
\text { Cases: } 1000 \\
\text { Controls: } 1000 \\
\text { Follow-up: } 10 \mathrm{y}\end{array}$ & $\begin{array}{c}\text { 25(OH)D level } 1 \text { y }(1 \mathrm{mo}-10 \mathrm{y}) \text { before diagnosis: } \\
\text { Cases: } 62.2 \pm 31.8 \mathrm{nmol} / \mathrm{L} \text {; Controls: } 72.5 \pm 33.0 \mathrm{nmol} / \mathrm{L} \\
\text { Adjusted OR of insulin-requiring DM for } 25(\mathrm{OH}) \mathrm{D} \text { level } \\
\text { [nmol/L]: } \\
<43 \mathrm{vs} \geq 100: 3.5(95 \% \mathrm{Cl} 2.0-6.0) \\
43-59 \mathrm{vs} \geq 100: 2.5(95 \% \mathrm{Cl} 1.5-4.2) \\
60-77 \mathrm{vs} \geq 100: 0.8(95 \% \mathrm{Cl} 0.4-1.4) \\
78-99 \mathrm{vs} \geq 100: 1.1(95 \% \mathrm{Cl} 0.6-2.8) \\
\text { P for trend (continuous): }<0.001\end{array}$ & $\begin{array}{l}\text { Significantly lower } 25(\mathrm{OH}) \mathrm{D} \text { level in cases } \\
\text { than in controls. Significant trend toward a } \\
\text { higher risk of insulin-requiring DM in } \\
\text { individuals with lower pre-diagnostic } \\
\text { serum 25(OH)D. }\end{array}$ & [139] \\
\hline USA & $\begin{array}{c}\text { Age: } \geq 20,6 \pm 4,0 \\
\text { Cases: } 310 \\
\text { Controls: } 613 \\
\text { Follow-up: } 5.4 \text { y }\end{array}$ & 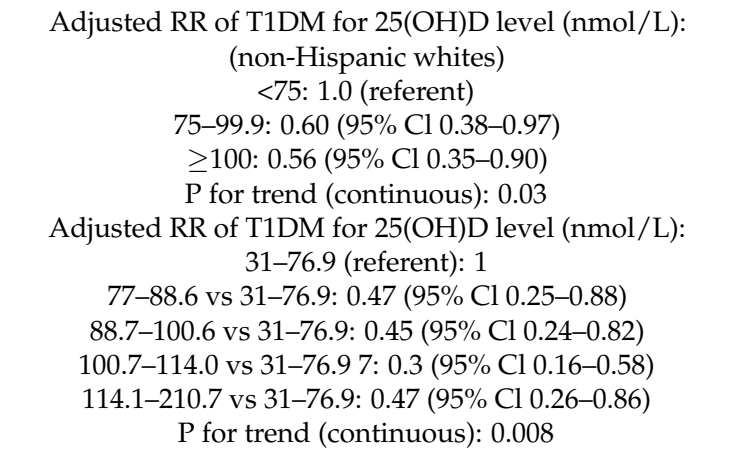 & $\begin{array}{l}\text { Significantly lower risk of T1DM in } \\
\text { non-Hispanic whites with pre-diagnostic } \\
\text { 25(OH)D level } \geq 100 \mathrm{nmol} / \mathrm{L} \text { than }<75 \\
\text { nmol/L. No significant association } \\
\text { between 25(OH)D level and the risk of } \\
\text { T1DM in non-Hispanic blacks and } \\
\text { Hispanics. Significant trend toward a } \\
\text { higher risk of T1DM in individuals with } \\
\text { lower 25(OH)D level. }\end{array}$ & [140] \\
\hline
\end{tabular}

IAab-islet autoantibodies; IA—islet autoimmunit. 
Table 4. Therapeutic role of vitamin D in patients with type 1 diabetes mellitus: interventional studies.

\begin{tabular}{|c|c|c|c|c|c|}
\hline Treatment Duration & Study Group & Supplementation Dosage * & $\begin{array}{l}\text { Significant Changes in } \\
\text { Biochemical Parameters }\end{array}$ & Clinical Findings & References \\
\hline 12-24 months & $\begin{array}{c}\mathrm{N}=31 ; \text { Age: } 15.7 \pm 1.4 \mathrm{y} \\
25(\mathrm{OH}) \mathrm{D} \\
<37.5 \mathrm{nmol} / \mathrm{L} \\
\text { Dd: } 6.8 \pm 3.5 \mathrm{y}\end{array}$ & $\begin{array}{l}\text { Cholecalciferol } \\
1000-2000 \mathrm{IU} / \mathrm{d}\end{array}$ & $\begin{array}{c}\uparrow 25(\mathrm{OH}) \mathrm{D}, \text { InRHI } \\
\downarrow \text { MCP-3, EGF, TNF- } \beta \text {, IL-10 }\end{array}$ & $\begin{array}{l}\text { Significant improvement in } \\
\text { endothelial function. } \\
\text { Significant decrease in } \\
\text { urinary inflammatory } \\
\text { cytokines. }\end{array}$ & [151] \\
\hline 12 weeks & $\mathrm{N}=22$ & $\begin{array}{c}\text { Cholecalciferol } \\
4000 \text { and 10,000 IU/d }\end{array}$ & $\begin{array}{c}\uparrow \text { Glycemia standard deviation } \\
\downarrow \text { DID }\end{array}$ & $\begin{array}{l}\text { Significant improvement in } \\
\text { glycemic variability, lower } \\
\text { insulin needs and lower } \\
\text { frequency of hypoglycemia. }\end{array}$ & [142] \\
\hline 3 months & $\begin{array}{c}\mathrm{N}=73 \\
\text { Age: } 7.7 \pm 4.4 \mathrm{y} \\
25(\mathrm{OH}) \mathrm{D}<75 \mathrm{nmol} / \mathrm{L} \\
\text { Dd: no data } \\
\end{array}$ & $\begin{array}{c}\text { Cholecalciferol } \\
6000 \mathrm{IU} / \mathrm{d} \text { (in vit. D-deficient } \\
\text { patients) or } 400 \mathrm{UI} / \mathrm{d} \text { (in vit. } \\
\text { D-insufficient patients) }\end{array}$ & $\begin{array}{l}\uparrow 25(\mathrm{OH}) \mathrm{D} \\
\downarrow \mathrm{HbA} 1 \mathrm{C}\end{array}$ & $\begin{array}{l}\text { Significant improvement in } \\
\text { glycemic control. }\end{array}$ & [149] \\
\hline 12 weeks & $\begin{array}{c}\mathrm{N}=30 ; \text { Age: } 5-15 \mathrm{y} \\
25(\mathrm{OH}) \mathrm{D}<75 \mathrm{nmol} / \mathrm{L} \\
\text { Dd: } 3.1 \pm 1.3 \mathrm{y}\end{array}$ & $\begin{array}{l}\text { Cholecalciferol } \\
50,000 \text { UI/week }\end{array}$ & $\begin{array}{c}\uparrow 25(\mathrm{OH}) \mathrm{D}, \text { IGF-1 } \\
\downarrow \text { HbA1C }\end{array}$ & $\begin{array}{l}\text { Significant improvement in } \\
\text { glycemic control and } \\
\text { prevention of its related } \\
\text { micro- and macrovascular } \\
\text { complication. }\end{array}$ & [150] \\
\hline 6 months & $\begin{array}{c}\mathrm{N}=39 \\
\text { Age: } 44(33-52) \mathrm{y} \\
\text { Dd: } 12.3(2.8-24.5) \mathrm{y}\end{array}$ & $\begin{array}{c}\text { Cholecalciferol } \\
4000 \mathrm{IU} / \mathrm{d} \text { for } 3 \text { mo followed by } \\
\text { placebo for } 3 \text { mo or in the } \\
\text { sequential alternative }\end{array}$ & $\begin{array}{l}\uparrow 25(\mathrm{OH}) \mathrm{D}, \mathrm{FCP} \\
\downarrow \mathrm{HbA1C}, \mathrm{DID} \\
\uparrow \text { Tregs }\left(\sigma^{7}\right)\end{array}$ & $\begin{array}{l}\text { Significant improvement in } \\
\text { glycemic control and } \\
\text { preservation of pancreatic } \\
\beta \text {-cells function In males, } \\
\text { increase in regulatory T cells. }\end{array}$ & [143] \\
\hline
\end{tabular}


Table 4. Cont

\begin{tabular}{|c|c|c|c|c|c|}
\hline Treatment Duration & Study Group & Supplementation Dosage * & $\begin{array}{l}\text { Significant Changes in } \\
\text { Biochemical Parameters }\end{array}$ & Clinical Findings & References \\
\hline 6 months & $\begin{array}{l}N=15+15 \\
\text { Age: } 6-12 y \\
\text { Dd: } 1-2 y\end{array}$ & $\begin{array}{l}\text { I: Cholecalciferol } \\
2000 \text { IU } / \mathrm{d}+\text { Ca } 25 \mathrm{mg} / \mathrm{kg} / \mathrm{d} \\
\text { II: Unsupplemented }\end{array}$ & $\begin{array}{c}\downarrow \text { Mean and monthly decrease in } \\
\text { SCP in supplemented group, } \\
\text { insignificant }\end{array}$ & $\begin{array}{l}\text { Trend toward lesser decline of } \\
\text { residual pancreatic } \beta \text {-cells } \\
\text { function in supplemented } \\
\text { patients. }\end{array}$ & [147] \\
\hline 12 months & $\begin{array}{c}\mathrm{N}=8+7 \\
\text { Age: } 12 \pm 0.9 \\
25(\mathrm{OH}) \mathrm{D}<20 \mathrm{ng} / \mathrm{mL} \\
\text { Dd: } 0.7 \pm 0.2 \mathrm{y}\end{array}$ & $\begin{array}{c}\text { I: Calcidiol } \\
10 \mu \mathrm{g} / \mathrm{d} \text { to reach } 50-80 \mathrm{ng} / \mathrm{mL} \\
\text { (reached after } 2 \mathrm{mo} \text { ) } \\
\text { II: Unsupplemented }\end{array}$ & $\begin{array}{c}\downarrow \text { reactivity of PBMCs against } \\
\text { GAD and pro-insulin in } \\
\text { supplemented group } \\
\text { FCP stable at } 12 \text { mo }\end{array}$ & $\begin{array}{l}\text { Significant inhibition of } \\
\text { autoagression and protective } \\
\text { effect on pancreatic } \beta \text {-cells } \\
\text { function in supplemented } \\
\text { patients. }\end{array}$ & [148] \\
\hline 24 months & $\begin{array}{c}\mathrm{N}=42 \\
\text { Age: } 12.7 \pm 3.1 \mathrm{y} \\
\text { 25(OH)D }<50 \mathrm{nmol} / \mathrm{L} \\
\text { Dd: } 4.8 \pm 3.3 \mathrm{y}\end{array}$ & $\begin{array}{c}\text { Cholecalciferol } \\
1 \text { dose of } 1000,000 \mathrm{IU} \\
(2-10 \mathrm{y}) \text { or } 1 \text { dose of } 160,000 \mathrm{IU} \\
(>10 \mathrm{y})\end{array}$ & $\begin{array}{l}\text { No difference in mean } \mathrm{HbA1C} \\
\text { level at } 3 \text { or at } 12 \text { months before } \\
\text { and after treatment. }\end{array}$ & No effect on glycemic control. & [156] \\
\hline
\end{tabular}


Table 5. Therapeutic role of vitamin D in patients with type 1 diabetes mellitus: randomized controlled trials (RCT).

\begin{tabular}{|c|c|c|c|c|c|}
\hline Study Design & Study Groups & $\begin{array}{l}\text { Supplementation } \\
\text { Dosage * }\end{array}$ & $\begin{array}{l}\text { Significant Changes in } \\
\text { Biochemical Parameters }\end{array}$ & Clinical Findings & References \\
\hline $\begin{array}{l}\text { RCT, DB, PC } \\
12 \text { months }\end{array}$ & $\begin{array}{l}\mathrm{N}=30(14+15) \\
\text { Age: } 12(11-17.5) \mathrm{y} \\
\text { Dd: } 61 \pm 20 \mathrm{~d}\end{array}$ & $\begin{array}{l}\text { I: Cholecalciferol } \\
70 \mathrm{IU} / \mathrm{kg} / \mathrm{d} \\
\text { II: Placebo }\end{array}$ & $\begin{array}{c}\uparrow \text { Suppressive capacity of Tregs in } \\
\text { suplemmented group in contrast } \\
\text { to placebo group }\end{array}$ & $\begin{array}{l}\text { Significant improvement in suppressor } \\
\text { function of Tregs in } \\
\text { supplemented patients }\end{array}$ & [153] \\
\hline $\begin{array}{l}\text { Prospective RCT } \\
12 \text { months }\end{array}$ & $\begin{array}{c}\mathrm{N}=35(18+17) \\
\text { Age: } 38.5 \pm 12.5 \mathrm{y} \\
\text { Dd: } 1.0(0.1-4.0) \mathrm{y} \\
\text { LADA patients }\end{array}$ & $\begin{array}{l}\text { I: Unsupplemented } \\
\text { II: Alfacalcidiol } 0.5 \mu \mathrm{g} / \mathrm{d}\end{array}$ & $\begin{array}{l}\text { I: } \downarrow \text { FCP, } 22 \% \text { had stable FCP } \\
\text { II: } 70 \% \text { had stable or } \uparrow \text { FCP }\end{array}$ & $\begin{array}{c}\text { Significant improvement in } \\
\text { preservation of pancreatic } \beta \text {-cells } \\
\text { function in supplemented patients, but } \\
\text { only with diabetes duration } \leq 12 \mathrm{mo}\end{array}$ & [144] \\
\hline $\begin{array}{c}\text { RCT } \\
12 \text { months }\end{array}$ & $\begin{array}{l}\mathrm{N}=67(34+33) \\
\text { Age: } 13.6 \pm 7.6 \mathrm{y} \\
\text { Dd: }<4 \text { weeks }\end{array}$ & $\begin{array}{l}\text { I: Calcitriol } 0.25 \mu \mathrm{g} / \mathrm{d} \\
\text { II: Nicotinamide } 25 \\
\mathrm{mg} / \mathrm{kg} / \mathrm{d}\end{array}$ & $\begin{array}{l}\text { I: } \downarrow \text { DID, but only at } 3 \text { and } 6 \text { mo } \\
\text { In both groups no changes in FCP } \\
\text { and HbA1C at } 12 \text { mo }\end{array}$ & $\begin{array}{l}\text { Modest effect on residual pancreatic } \\
\beta \text {-cells function and only temporarily } \\
\text { reduction of insulin dose in calcitriol- } \\
\text { supplemented patients. }\end{array}$ & [146] \\
\hline $\begin{array}{l}\text { RCT, DB, PC } \\
18 \text { months }\end{array}$ & $\begin{array}{l}\mathrm{N}=38(19+19) \\
\text { Age: } 13.5 \pm 5.1 \mathrm{y} \\
\text { Dd: } 2.2 \pm 1.2 \mathrm{mo}\end{array}$ & $\begin{array}{l}\text { I: Cholecalciferol } 2000 \\
\text { IU } / \mathrm{d} \\
\text { II: Placebo }\end{array}$ & $\begin{array}{c}\uparrow \text { Chemokine ligand } 2 \text { at } 12 \mathrm{mo} \\
\uparrow \mathrm{SCP} \text { and Tregs } \% \text { at } 12 \mathrm{mo} \\
\downarrow \text { Progression to undetectable } \\
\text { FCP at } 18 \text { mo }\end{array}$ & $\begin{array}{l}\text { Protective immunological effect and } \\
\text { slowing down the decline of residual } \\
\text { pancreatic } \beta \text {-cells function in } \\
\text { supplemented patients. }\end{array}$ & [152] \\
\hline $\begin{array}{l}\text { RCT, SB, PC } \\
6 \text { months }\end{array}$ & $\begin{array}{l}\mathrm{N}=54(29+25) \\
\text { Age: } 10.2 \pm 2.5 \mathrm{y} \\
\text { Dd: } 44 \pm 14 \mathrm{~d}\end{array}$ & $\begin{array}{l}\text { I: Alfacalcidiol } 0.5 \mu \mathrm{g} / \mathrm{d} \\
\text { II: Placebo }\end{array}$ & $\begin{array}{c}\uparrow \mathrm{FCP} \\
\downarrow \mathrm{DID} \\
\text { Stronger response in males. }\end{array}$ & $\begin{array}{l}\text { Improvement in preservation of } \\
\text { pancreatic } \beta \text {-cells function in } \\
\text { supplemented patients with a stronger } \\
\text { effect in males. }\end{array}$ & [145] \\
\hline $\begin{array}{l}\text { RCT, DB, PC } \\
24 \text { months }\end{array}$ & $\begin{array}{l}\mathrm{N}=27(15+12) \\
\text { Age: } 18(11-35) \text { y } \\
\text { Dd: }<12 \text { weeks }\end{array}$ & $\begin{array}{l}\text { I: Calcitriol } 0.25 \mu \mathrm{g} / \mathrm{d} \\
\text { II: Placebo }\end{array}$ & $\begin{array}{l}\text { No differences in FCP, HbA1C } \\
\text { and DID between groups. }\end{array}$ & $\begin{array}{c}\text { No protective effect on pancreatic } \\
\beta \text {-cells function in } \\
\text { supplemented patients. }\end{array}$ & [154] \\
\hline $\begin{array}{l}\text { RCT, DB, PC } \\
18 \text { months }\end{array}$ & $\begin{array}{l}\mathrm{N}=40(22+18) \\
\text { Age: } 31.4 \pm 6.8 \mathrm{y} \\
\text { Dd: } 35 \mathrm{~d}\end{array}$ & $\begin{array}{l}\text { I: Calcitriol } 0.25 \mu \mathrm{g} / \mathrm{d} \\
\text { II: Placebo }\end{array}$ & $\begin{array}{c}\text { No differences in FCP and DID } \\
\text { between groups. }\end{array}$ & $\begin{array}{c}\text { No protective effect on pancreatic } \\
\beta \text {-cells function in } \\
\text { supplemented patients. }\end{array}$ & [155] \\
\hline
\end{tabular}

SCP-stimulated C-peptid. 


\section{Conclusions}

T1DM is a chronic autoimmune disease associated with pancreatic $\beta$-cell degeneration that results in the inability to produce insulin and the consequent need for exogenous insulin administration. It is a significant global health problem, since the incidence of this disorder is increasing worldwide, and health complications are very serious, affect many organs and bring high economic expenditures for patients and countries. Thus, this disease is a significant challenge for healthcare systems and raises the need to search for low-cost adjuvant therapies in diabetic patients.

The potential of vitamin D as a therapy for T1DM patients is apparent. Its immunomodulatory properties, which promote the induction of immune tolerance and T cell anergy, impair B cell activity and antibody production as well as reduce the inflammatory response (Table 1), exert beneficial effects for prevention (Tables 2 and 3) and treatment of T1DM (Tables 4 and 5). However, it should be emphasised that many clinical intervention studies that used various forms of vitamin $\mathrm{D}$ for the prevention of T1DM or in patients already affected with the disease have been disappointing.

The alarming fact is that epidemiological studies have demonstrated a worldwide high prevalence of vitamin D deficiency or insufficiency. The problem of vitamin D deficiency is widely known, especially in patients with T1DM. Insufficient vitamin D is not only a consequence of disease, but it seems to be primarily a strong dietary trigger. Adequate vitamin D supplementation in childhood appears to exert a protective effect and decrease the risk of T1DM later in life. Thus, recommendations on daily vitamin $\mathrm{D}$ intake and supplementation should be followed by all age groups, particularly infants and children.

Concern for the optimal status of vitamin D, especially in early life, is an important preventative element of T1DM. Nevertheless, additional studies are needed to establish appropriate vitamin D dosage and form (cholecalciferol, alfacalcidiol or calcitriol) used as an adjuvant therapy with insulin treatment, adjusted for individual needs of diabetic patients (age, degree of vitamin D deficiency or insufficiency, duration of diabetes and current insulin needs). Importantly, vitamin D supplementation up to 10,000 IU per day is a safe and tolerable upper level intake for adults (determined by the Unites States Institute of Medicine). This finding opens the door for treatment trials with vitamin D levels high enough to effectively reduce T1DM incidence and complications. Recent reports indicate new directions for further research on this issue and suggest that future recommended daily vitamin $\mathrm{D}$ intake in various human populations, as well as supplementation dosage in patients with T1DM, may depend on polymorphisms in genes involved in the vitamin D metabolic pathway and on the personal vitamin $\mathrm{D}$ response index.

Author Contributions: K.R. and M.B. conceived and designed the review; K.R. wrote the paper.

Funding: This work was supported by the Wroclaw Centre of Biotechnology, programme The Leading National Research Centre (KNOW) for years 2014-2018 [Grant number P/2016/4].

Conflicts of Interest: The authors declare no conflict of interest. The founding sponsors had no role in the design of the review; in the writing of the manuscript, and in the decision to publish the papers.

\section{References}

1. Paschou, S.A.; Papadopoulou-Marketou, N.; Chrousos, G.P.; Kanaka-Gantenbein, C. On type 1 diabetes mellitus pathogenesis. Endocr. Connect. 2018, 7, 38-46. [CrossRef] [PubMed]

2. Noble, J.A.; Erlich, H.A. Genetics of type 1 diabetes. Cold Spring Harb. Perspect. Med. 2012, 2, 1-15. [CrossRef] [PubMed]

3. Frese, T.; Sandholzer, H. The epidemiology of type 1 diabetes mellitus. In Type 1 Diabetes; Escher, S., Li, A., Eds.; IntechOpen: London, UK, 2013; pp. 1-22.

4. World Health Organization. Global Report on Diabetes. 2016. Available online: http: / /apps.who.int/iris/bitstream/handle/10665/204871/9789241565257_eng.pdf;jsessionid= CCC2429A03D7EF6D638C05F6F008A3C2?sequence=1 (accessed on 17 September 2018). 
5. IDF Diabetes Atlas-8th edition, 2017. International Diabetes Federation. Available online: http://www. diabetesatlas.org/across-the-globe.html (accessed on 17 September 2018).

6. Al-Lawati, J.A. Diabetes mellitus: A local and global public health emergency! Oman Med. J. 2017, 32, 177-179. [CrossRef] [PubMed]

7. Pociot, F.; Lernmark, A. Genetic risk factorsk for type 1 diabetes. Lancet 2016, 387, 2331-2339. [CrossRef]

8. Ziegler, A.G.; Rewers, M.; Simell, O.; Simmel, T.; Lempainen, J.; Steck, A.; Winkler, C.; Ilonen, J.; Veijola, R.; Knip, M.; et al. Seroconversion to multiple islet autoantibodies and risk of progression to diabetes in children. JAMA 2013, 309, 2473-2479. [CrossRef]

9. Pociot, F.; Akolkar, B.; Concannon, P.; Erlich, H.A.; Julier, C.; Morahan, G.; Nierras, C.R.; Todd, J.A.; Rich, S.S.; Nerup, J. Genetics of type 1 diabetes: What's next? Diabetes 2010, 59, 1561-1571. [CrossRef] [PubMed]

10. Rewers, M.; Davis, B.; Ludvigsson, J. Environmental risk factors for type 1 diabetes. Lancet 2016, 387, 2340-2348. [CrossRef]

11. Gerard-Gonzalez, A.; Adi, S. Type 1 diabetes mellitus: An overview. In Nutritional and therapeutic interventions for diabetes and metabolic syndrome, 2nd ed.; Bagchi, D., Nair, S., Eds.; Elsevier Academic Press: London, UK, 2018.

12. Backman, V.M.; Thorsson, A.V.; Fasquel, A.; Andrason, H.S.; Kristjansson, K.; Gulcher, J.R.; Stefansson, K. HLA class II alleles and haplotypes in Icelandic type I diabetic patients: Comparison of Icelandic and Norwegian populations. Diabetologia 2002, 45, 452-453.

13. Karvonen, M.; Viik-Kajander, M.; Moltchanova, E.; Libman, I.; LaPorte, R.; Tuomilehto, J. Incidence of childhood type 1 diabetes worldwide. Diabetes mondiale (DiaMond) project group. Diabetes Care 2000, 23, 1516-1526. [CrossRef]

14. Kondrashova, A.; Reunanen, A.; Romanov, A.; Karvonen, A.; Viskari, H.; Vesikari, T.; Ilonen, J.; Knip, M.; Hyöty, H. A six-fold gradient in the incidence of type 1 diabetes at the eastern border of Finland. Ann. Med. 2005, 37, 67-72. [CrossRef]

15. Oilinki, T.; Otonkoski, T.; Ilonen, J.; Knip, M.; Miettinen, P.J. Prevalence and characteristics of diabetes among Somali children and adolescents living in Helsinki, Finland. Pediatr. Diabetes 2012, 13, 176-180. [CrossRef] [PubMed]

16. Barnett, A.H.; Eff, C.; Leslie, R.D.; Pyke, D.A. Diabetes in identical twins. A study of 200 pairs. Diabetologia 1981, 20, 87-93. [CrossRef] [PubMed]

17. Coppieters, K.T.; Wiberg, A.; Tracy, S.M.; von Herrath, M.G. Immunology in the clinic review series; focus on type 1 diabetes and viruses: The role of viruses in type 1 diabetes: A difficult dilemma. Clin. Exp. Immunol. 2012, 168, 5-11. [CrossRef] [PubMed]

18. Stene, L.C.; Rewers, M. Immunology in the clinic review series; focus on type 1 diabetes and viruses: The enterovirus link to type 1 diabetes: Critical review of human studies. Clin. Exp. Immunol. 2012, 168, 12-23. [CrossRef] [PubMed]

19. Richardson, S.J.; Willcox, A.; Bone, A.J.; Foulis, A.K.; Morgan, N.G. The prevalence of enteroviral capsid protein vp1 immunostaining in pancreatic islets in human type 1 diabetes. Diabetologia 2009, 52, 1143-1151. [CrossRef] [PubMed]

20. Krogvold, L.; Edwin, B.; Buanes, T.; Frisk, G.; Skog, O.; Anagandula, M.; Korsgren, O.; Undlien, D.; Eike, M.C.; Richardson, S.J.; et al. Detection of a low-grade enteroviral infection in the islets of langerhans of living patients newly diagnosed with type 1 diabetes. Diabetes 2015, 64, 1682-1687. [CrossRef] [PubMed]

21. Richardson, S.J.; Leete, P.; Bone, A.J.; Foulis, A.K.; Morgan, N.G. Expression of the enteroviral capsid protein VP1 in the islet cells of patients with type 1 diabetes is associated with induction of protein kinase $\mathrm{R}$ and downregulation of Mcl-1. Diabetologia 2013, 56, 185-193. [CrossRef] [PubMed]

22. Morgan, N.G.; Richardson, S.J. Enteroviruses as causative agents in type 1 diabetes: Loose ends or lost cause? Trends Endocrinol. Metab. 2014, 25, 611-619. [CrossRef] [PubMed]

23. de Goffau, M.C.; Luopajärvi, K.; Knip, M.; Ilonen, J.; Ruohtula, T.; Härkönen, T.; Orivuori, L.; Hakala, S.; Welling, G.W.; Harmsen, H.J.; et al. Fecal microbiota composition differs between children with $\beta$-cell autoimmunity and those without. Diabetes 2013, 62, 1238-1244. [CrossRef] [PubMed]

24. Murri, M.; Leiva, I.; Gomez-Zumaquero, J.M.; Tinahones, F.J.; Cardona, F.; Soriqer, F.; Queipo-Ortuno, M.I. Gut microbiota in children with type 1 diabetes differs from that in healthy children: A case-control study. BMC Med. 2013, 11, 46. [CrossRef] [PubMed] 
25. Kostic, A.D.; Gevers, D.; Siljander, H.; Knip, M.; on behalf of the DIABIMMUNE Study Group. The dynamics of the human infant gut microbiome in development and in progression toward type 1 diabetes. Cell Host Microbe 2015, 17, 260-273. [CrossRef] [PubMed]

26. Graves, P.M.; Barriga, K.J.; Norris, J.M.; Hoffman, M.R.; Yu, L.; Eisenbarth, G.S.; Rewers, M. Lack of association between early childhood immunizations and beta-cell autoimmunity. Diabetes Care 1999, 22, 1694-1697. [CrossRef] [PubMed]

27. Hummel, M.; Füchtenbusch, M.; Schenker, M.; Ziegler, A.G. No major association of breast-feeding, vaccinations, and childhood viral diseases with early islet autoimmunity in the German BABYDIAB Study. Diabetes Care 2000, 23, 969-974. [CrossRef] [PubMed]

28. Jefferson, T.; Demicheli, V. No evidence that vaccines cause insulin dependent diabetes mellitus. J. Epidemiol. Commun. Health 1998, 52, 674-675. [CrossRef]

29. Offit, P.A.; Hackett, C.J. Addressing parents' concerns: Do vaccines cause allergic or autoimmune diseases? Pediatrics 2003, 111, 653-659. [CrossRef] [PubMed]

30. Morgan, E.; Halliday, S.R.; Campbell, G.R.; Cardwell, C.R.; Patterson, C.C. Vaccinations and childhood type 1 diabetes mellitus: A meta-analysis of observational studies. Diabetologia 2016, 59, 237-243. [CrossRef] [PubMed]

31. Holmberg, H.; Wahlberg, J.; Vaarala, O.; Ludvigsson, J.; For the ABIS Study Group. Short duration of breast-feeding as a risk-factor for beta-cell autoantibodies in 5-year-old children from the general population. Br. J. Nutr. 2007, 97, 111-116. [CrossRef]

32. Norris, J.M.; Barriga, K.; Klingensmith, G.; Hoffman, M.; Eisenbarth, G.S.; Erlich, H.A.; Rewers, M. Timing of initial cereal exposure in infancy and risk of islet autoimmunity. JAMA 2003, 290, 1713-1720. [CrossRef]

33. Frederiksen, B.; Kroehl, M.; Lamb, M.M.; Seifert, J.; Barriga, K.; Eisenbarth, G.S.; Rewers, M.; Norris, J.M. Infant exposures and development of type 1 diabetes mellitus: The diabetes autoimmunity study in the young (DAISY). JAMA Pediatr. 2013, 167, 808-815. [CrossRef]

34. Couper, J.J.; Steele, C.; Beresford, S.; Powell, T.; McCaul, K.; Pollard, A.; Gellert, S.; Tait, B.; Harrison, L.C.; Colman, P.G. Lack of association between duration of breast-feeding or introduction of cow's milk and development of islet autoimmunity. Diabetes 1999, 48, 2145-2149. [CrossRef]

35. Ziegler, A.G.; Schmid, S.; Huber, D.; Hummel, M.; Bonifacio, E. Early infant feeding and risk of developing type 1 diabetes-associated autoantibodies. JAMA 2003, 290, 1721-1728. [CrossRef] [PubMed]

36. Virtanen, S.M.; Takkinen, H.M.; Nevalainen, J.; Kronberg-Kippilä, C.; Salmenhaara, M.; Uusitalo, L.; Kenward, M.G.; Erkkola, M.; Veijola, R.; Simell, O.; et al. Early introduction of root vegetables in infancy associated with advanced $\beta$-cell autoimmunity in young children with human leukocyte antigen-conferred susceptibility to Type 1 diabetes. Diabetes Med. 2011, 28, 965-971. [CrossRef] [PubMed]

37. Virtanen, S.M.; Nevalainen, J.; Kronberg-Kippilä, C.; Ahonen, S.; Tapanainen, H.; Uusitalo, L.; Takkinen, H.M.; Niinistö, S.; Ovaskainen, M.L.; Kenward, M.G.; et al. Food consumption and advanced $\beta$ cell autoimmunity in young children with HLA-conferred susceptibility to type 1 diabetes: A nested case-control design. Am. J. Clin. Nutr. 2012, 95, 471-478. [CrossRef] [PubMed]

38. Wahlberg, J.; Vaarala, O.; Ludvigsson, J.; For the ABIS-Study Group. Dietary risk factors for the emergence of type 1 diabetes-related autoantibodies in 21/2 year-old Swedish children. Br. J. Nutr. 2006, 95, 603-608. [CrossRef] [PubMed]

39. Hummel, S.; Pflüger, M.; Hummel, M.; Bonifacio, E.; Ziegler, A.G. Primary dietary intervention study to reduce the risk of islet autoimmunity in children at increased risk for type 1 diabetes: The BABYDIET study. Diabetes Care 2011, 34, 1301-1305. [CrossRef]

40. Hummel, M.; Bonifacio, E.; Naserke, H.E.; Ziegler, A.G. Elimination of dietary gluten does not reduce titers of type 1 diabetes-associated autoantibodies in high-risk subjects. Diabetes Care 2002, 25, 1111-1116. [CrossRef] [PubMed]

41. Knip, M.; Åkerblom, H.K.; Becker, D.; Dosh, H.-M.; Dupre, J.; Fraser, W.; Howard, N.; Ilonen, J.; Krischer, J.P.; Kordonouri, O.; et al. Hydrolyzed infant formula and early $\beta$-cell autoimmunity: A randomized clinical trial. JAMA 2014, 311, 2279-2287. [CrossRef] [PubMed]

42. Villagrán-García, E.F.; Hurtado-López, E.F.; Vasquez-Garibay, E.M.; Troyo-Sanromán, R.; Aguirre-Salas, L.M.; Larrosa-Haro, A.; León-Robles, R.V. Introduction of pasteurized/raw cow's milk during the second semester of life as a risk factor of type 1 diabetes mellitus in school children and adolescents. Nutr. Hosp. 2015, 32, 634-637. 
43. Lamb, M.M.; Miller, M.; Seifert, J.A.; Frederiksen, B.; Kroehl, M.; Rewers, M.; Norris, J.M. The effect of childhood cow's milk intake and HLA-DR genotype on risk of islet autoimmunity and type 1 diabetes: The diabetes autoimmunity study in the young. Pediatr. Diabetes 2015, 16, 31-38. [CrossRef]

44. Virtanen, S.M.; Läärä, E.; Hyppönen, E.; Reijonen, H.; Räsänen, L.; Aro, A.; Knip, M.; Ilonen, J.; Akerblom, H.K. Cow's milk consumption HLA-DQB1 genotype type 1 diabetes: A nested case-control study of siblings of children with diabetes Childhood diabetes in Finland study group. Diabetes 2000, 49, 912-917. [CrossRef] [PubMed]

45. Verge, C.F.; Howard, N.J.; Irwig, L.; Simpson, J.M.; Mackerras, D.; Silink, M. Environmental factors in childhood IDDM A population-based, case-control study. Diabetes Care 1994, 17, 1381-1389. [CrossRef] [PubMed]

46. Rosenbauer, J.; Herzig, P.; Giani, G. Early infant feeding and risk of type 1 diabetes mellitus-a nationwide population-based case-control study in pre-school children. Diabetes Metab. Res. Rev. 2008, 24, 211-222. [CrossRef]

47. Chia, J.S.J.; McRae, J.L.; Kukuljan, S.; Woodford, K.; Elliott, R.B.; Swinburn, B.; Dwyer, K.M. A1 beta-casein milk protein and other environmental pre-disposing factors for type 1 diabetes. Nutr. Diabetes 2017, 7, e274. [CrossRef] [PubMed]

48. Muntoni, S.; Muntoni, S. Epidemiological association between some dietary habits and the increasing incidence of type 1 diabetes worldwide. Ann. Nutr. Metab. 2006, 50, 11-19. [CrossRef] [PubMed]

49. Muntoni, S.; Mereu, R.; Atzori, L.; Mereu, A.; Galassi, S.; Corda, S.; Frongia, P.; Angius, E.; Pusceddu, P.; Contu, P.; et al. High meat consumption is associated with type 1 diabetes mellitus in a Sardinian case-control study. Acta Diabetol. 2013, 50, 713-719. [CrossRef] [PubMed]

50. Niinistö, S.; Takkinen, H.-M.; Uusitalo, L.; Rautanen, J.; Vainio, N.; Ahonen, S.; Nevalainen, J.; Kenward, M.G.; Lumia, M.; Simell, O.; et al. Maternal intake of fatty acids and their food sources during lactation and the risk of preclinical and clinical type 1 diabetes in the offspring. Acta Diabetol. 2015, 52, 763-772.

51. Dahlquist, G.G.; Blom, L.G.; Persson, L.A.; Sandström, A.I.; Wall, S.G. Dietary factors and the risk of developing insulin dependent diabetes in childhood. BMJ 1990, 300, 1302-1306. [CrossRef]

52. Äkerblom, H.K.; Vaarala, O.; Hyöty, H.; Ilonen, J.; Knip, M. Environmental factors in the etiology of type 1 diabetes. Am. J. Med. Genet. 2002, 115, 18-29. [CrossRef]

53. Virtaten, S.M.; Knip, M. Nutritional risk predictors of $\beta$-cell autoimmunity and type 1 diabetes at young age. Am. J. Clin. Nutr. 2003, 78, 1053-1067. [CrossRef]

54. Abd-Allah, S.H.; Pasha, H.F.; Hagrass, H.A.; Alghobashy, A.A. Vitamin D status and vitamin D receptor gene polymorphisms and susceptibility to type 1 diabetes in Egyptian children. Gene 2014, 536, 430-434. [CrossRef]

55. Ali, R.; Fawzy, I.; Mohsen, I.; Settin, A. Evaluation of vitamin D receptor gene polymorphisms (Fok-I and Bsm-I) in T1DM Saudi children. J. Clin. Lab. Anal. 2018, 32, e22397. [CrossRef] [PubMed]

56. Wang, G.; Zhang, Q.; Xu, N.; Xu, K.; Wang, J.; He, W.; Yang, T. Association between two polymorphisms (FokI and BsmI) of vitamin D receptor gene and type 1 diabetes mellitus in Asian population: A meta-analysis. PLoS ONE 2014, 9, e89325. [CrossRef] [PubMed]

57. Sahin, O.A.; Goksen, D.; Ozpinar, A.; Serdar, M.; Onay, H. Association of vitamin D receptor polymorphisms and type 1 diabetes susceptibility in children: A meta-analysis. Endocr. Connect. 2017, 6, 159-171. [CrossRef] [PubMed]

58. Chang, T.J.; Lei, H.H.; Yeh, J.I.; Chiu, K.C.; Lee, K.C.; Chen, M.C.; Tai, T.Y.; Chuang, L.M. Vitamin D receptor gene polymorphisms influence susceptibility to type 1 diabetes mellitus in the Taiwanese population. Clin. Endocrinol. 2000, 52, 575-580. [CrossRef]

59. Mukhtar, M.; Batool, A.; Wajid, A.; Qayyum, I. Vitamin D receptor gene polymorphisms influence T1D susceptibility among Pakistanis. Int. J. Genomics 2017, e4171254. [CrossRef] [PubMed]

60. Panierakis, C.; Gouliemos, G.; Mamoulakis, D.; Petraki, E.; Papavasiliou, E.; Galanakis, E. Vitamin D receptor gene polymorphisms and susceptibility to type 1 diabetes in Crete, Greece. Clin. Immunol. 2009, 133, $276-281$. [CrossRef]

61. Tizaoui, K.; Kaabachi, W.; Hamzaoui, A.; Hamzaoui, K. Contribution of VDR polymorphisms to Type 1 diabetes susceptibility: A systematic review of case-control studies and meta-analysis. J. Steroid. Biochem. Mol. Biol. 2014, 143, 240-249. [CrossRef] 
62. Nykjaer, A.; Dragun, D.; Walther, D.; Vorum, H.; Jacobsen, C.; Herz, J.; Melsen, F.; Christensen, E.I.; Willnow, T.E. An endocytic pathway essential for renal uptake and activation of the steroid $25(\mathrm{OH})$ vitamin D3. Cell 1999, 96, 507-515. [CrossRef]

63. Arnaud, J.; Constans, J. Affinity differences for vitamin D metabolites associated with the genetic isoforms of the human serum carrier protein (DBP). Hum. Genet. 1993, 92, 183-188. [CrossRef]

64. Bouillon, R.; Van Assche, F.A.; Van Baelen, H.; Heyns, W.; De Moor, P. Influence of the vitamin D-binding protein on the serum concentration of 1.25-dihydroxyvitamin D3. Significance of the free 1.25-dihydroxyvitamin D3 concentration. J. Clin. Investig. 1981, 67, 589-596. [CrossRef]

65. Ongagna, J.C.; Pinget, M.; Belcourt, A. Vitamin D-binding protein gene polymorphism association with IA-2 autoantibodies in type 1 diabetes. Clin. Biochem. 2005, 38, 415-419. [CrossRef] [PubMed]

66. Ongagna, J.C.; Kaltenbacher, M.C.; Sapin, R.; Pinget, M.; Belcourt, A. The HLA-DQB alleles and amino acid variants of the vitamin Dbinding protein in diabetic patients in Alsace. Clin. Biochem. 2001, 34, 59-63. [CrossRef]

67. Thorsen, S.U.; Mortensen, H.B.; Carstensen, B.; Fenger, M.; Thuesen, B.H.; Husemoen, L.; Bergholdt, R.; Brorsson, C.; Pociot, F.; Linneberg, A.; et al. No association between type 1 diabetes and genetic variation in vitamin D metabolism genes: A Danish study. Pediatr. Diabetes 2014, 15, 416-421. [CrossRef] [PubMed]

68. Blanton, D.; Han, Z.; Bierschenk, L.; Linga-Reddy, M.V.; Wang, H.; Clare-Salzler, M.; Haller, M.; Schatz, D.; Myhr, C.; She, J.X.; et al. Reduced serum vitamin D binding protein levels are associated with type 1 diabetes. Diabetes 2011, 60, 2566-2570. [CrossRef] [PubMed]

69. Hussein, A.G.; Mohamed, R.H.; Alghobashy, A.A. Synergism of CYP2R1 and CYP27B1 polymorphisms and susceptibility to type 1 diabetes in Egyptian children. Cell Immunol. 2012, 279, 42-45. [CrossRef] [PubMed]

70. Cooper, J.D.; Smyth, D.J.; Walker, N.M.; Stevens, H.; Burren, O.S.; Wallace, C.; Greissl, C.; Ramos-Lopez, E.; Hyppönen, E.; Dunger, D.B.; et al. Inherited variation in vitamin D genes is associated with predisposition to autoimmune disease type 1 diabetes. Diabetes 2011, 60, 1624-1631. [CrossRef] [PubMed]

71. Ramos-Lopez, E.; Brück, P.; Jansen, T.; Herwig, J.; Badenhoop, K. CYP2R1 (vitamin D 25-hydroxylase) gene is associated with susceptibility to type 1 diabetes and vitamin D levels in Germans. Diabetes Metab. Res. Rev. 2007, 23, 631-636. [CrossRef]

72. Bailey, R.; Cooper, J.D.; Zeitels, L.; Smyth, D.J.; Yang, J.H.; Walker, N.M.; Hyppönen, E.; Dunger, D.B.; Ramos-Lopez, E.; Badenhoop, K.; et al. Association of the vitamin D metabolism gene CYP27B1 with type 1 diabetes. Diabetes 2007, 56, 2616-2621. [CrossRef]

73. Olędzka, R. Vitamin D in the light of the research of the last years. Bromat. Chem. Toksykol. 2013, 46, 121-131. (In Polish)

74. Zhang, R.; Naughton, D.P. Vitamin D in health and disease: Current perspectives. Nutr. J. 2010, 9, 65. [CrossRef]

75. Holick, M.F. The vitamin D deficiency pandemic: Approaches for diagnosis, treatment and prevention. Rev. Endoc.r Metab. Disord. 2017, 18, 153-165. [CrossRef] [PubMed]

76. Holick, M.F.; Binkley, N.C.; Bischoff-Ferrari, H.A.; Gordon, C.M.; Hanley, D.A.; Heaney, R.P.; Murad, M.H.; Weaver, C.M. Evaluation, treatment, and prevention of vitamin D deficiency: An endocrine society clinical practice guidline. J. Clin. Endocrinol. Metab. 2011, 96, 1911-1930. [CrossRef] [PubMed]

77. Płudowski, P.; Karczmarewicz, E.; Bayer, M.; Carter, G.; Chlebna-Sokół, D.; Czech-Kowalska, J.; Dębski, R.; Desci, T.; Dobrzańska, A.; Franek, E.; et al. Practical guidelines for the supplementation of vitamin D and the treatment of deficits in Central Europe-recommended vitamin D intakes in general population and groups at risk of vitamin D deficiency. Endokrynol. Pol. 2013, 64, 319-327. [CrossRef] [PubMed]

78. Rusińska, A.; Płudowski, P.; Walczak, M.; Borszewska-Kornacka, M.K.; Bossowski, A.; Chlebna-Sokół, D.; Czech-Kowalska, J.; Dobrzańska, A.; Franek, E.; Helwich, E.; et al. Vitamin D supplementation guidelines for general population and groups at risk of Vitamin D deficiency in Poland-recommendations of the Polish society of pediatric endocrinology and diabetes and the expert panel with participation of national specialist consultants and representatives of scientific societies-2018 update. Front. Endocrinol. 2018, 9, 246. [CrossRef]

79. IOM (Institute of Medicine); Committee to Review Dietary Reference Intakes for Calcium and Vitamin D. Dietary Reference Intakes for Calcium and Vitamin D; National Academies Press: Washington, DC, USA, 2011.

80. Carlberg, C.; Hag, A. The concept of the personal vitamin D response index. J. Steroid. Biochem. Mol. Biol. 2018, 175, 12-17. [CrossRef] [PubMed] 
81. Fischer, P.R.; Thacher, T.D.; Pettifor, J.M. Pediatric vitamin D and calcium nutrition in developing countries. Rev. Endocr. Metab. Disord. 2008, 9, 181-192. [CrossRef] [PubMed]

82. Zhu, Z.; Zhan, J.; Shao, J.; Chen, W.; Chen, L.; Li, W.; Ji, C.; Zhao, Z. High prevalence of vitamin D deficiency among children aged 1 month to 16 years in Hangzhou, China. BMC Public Health 2012, 12, 126. [CrossRef]

83. Shivane, V.K.; Sarathi, V.; Bandgar, T.; Menon, P.; Shan, N.S. High prevalence of hypovitaminosis D in young healthy adults from the western part of India. Postgrad. Med. J. 2011, 87, 514-518. [CrossRef]

84. González-Gross, M.; Valtueña, J.; Breidenassel, C.; Moreno, L.A.; Ferrari, M.; Kersting, M.; De Henauw, S.; Gottrand, F.; Azzini, E.; Widhalm, K.; et al. Vitamin D status among adolescents in Europe: The healthy lifestyle in Europe by nutrition in adolescence study. Br. J. Nutr. 2012, 107, 755-764. [CrossRef]

85. Pilz, S.; März, W.; Cashman, K.D.; Kiely, M.E.; Whiting, S.J.; Holick, M.F.; Grant, W.B.; Pludowski, P.; Hiligsmann, M.; Trummer, C.; et al. Rationale and plan for vitamin D food fortification: A review and guidance paper. Front. Endocrinol. 2018, 17, 373. [CrossRef]

86. Jääskeläinen, T.; Itkonen, S.T.; Lundqvist, A.; Erkkola, M.; Koskela, T.; Lakkala, K.; Dowling, K.G.; Hull, G.L.; Kröger, H.; Karppinen, J.; et al. The positive impact of general vitamin D food fortification policy on vitamin D status in a representative adult Finnish population: Evidence from an 11-y follow-up based on standardized 25-hydroxyvitamin D data. Am. J. Clin. Nutr. 2017, 105, 1512-1520. [CrossRef] [PubMed]

87. Dankers, W.; Colin, E.M.; van Hamburg, J.P.; Lubberts, E. Vitamin D in autoimmunity: Molecular mechanism and therapeutic potential. Front. Immunol. 2017, 7, 697. [CrossRef] [PubMed]

88. Napiórkowska, L.; Franek, E. The role of vitamin D determination in clinical practice. Choroby Serca i Naczyń 2009, 6, 203-210. (In Polish)

89. Yu, C.; Xue, H.; Wang, L.; Chen, Q.; Chen, X.; Zhang, Y.; Hu, G.; Ling, W. Serum bioavailable and free 25-hydroksyvitamin D levels, but not its total level, are associated with the risk of mortality in patients with coronary artery disease. Circ. Res. 2018, 123, 996-1007. [CrossRef]

90. Norman, P.E.; Powell, J.T. Vitamin D and cardiovascular disease. Circ. Res. 2014, 114, 379-393. [CrossRef] [PubMed]

91. Overbergh, L.; Dacallonne, B.; Valckx, D.; Verstuyf, A.; Depovere, J.; Laureys, J.; Rutgeerts, O.; Saint-Arnaud, R.; Bouillon, R.; Mathieu, C. Identification and immune regulation of 25-hydroxyvitamin D-1-alpha-hydroxylase in murine macrophages. Clin. Exp. Immunol. 2000, 120, 139-146. [CrossRef] [PubMed]

92. Korf, H.; Wenes, M.; Stijlemans, B.; Takiishi, T.; Robert, S.; Miani, M.; Eizirik, D.L.; Gysemans, C.; Mathieu, C. 1,25-dihy-droxyvitamin D3 curtails the inflammatory and T cell stimulatory capacity of macrophages through an IL-10-dependent mechanism. Immunobiology 2012, 217, 1292-1300. [CrossRef] [PubMed]

93. Chen, Y.; Liu, W.; Sun, T.; Huang, Y.; Wang, Y.; Deb, D.K.; Yoon, D.; Kong, J.; Thadhani, R.; Li, Y.C. 1,25-Dihydroxyvitamin $\mathrm{D}$ promotes negative feedback regulation of TLR signaling via targeting micro RNA-155-SOCS1 in macrophages. J. Immunol. 2013, 190, 3687-3695. [CrossRef] [PubMed]

94. Neve, A.; Corrado, A.; Cantatore, F.P. Immunomodulatory effects of vitamin D in peripheral blood monocyte-derived macrophages from patients with rheumatoid arthritis. Clin. Exp. Med. 2014, 14, 275-283. [CrossRef]

95. Zhang, X.; Zhou, M.; Guo, Y.; Song, Z.; Liu, B. 1,25-dihydroxyvitamin D3 promotes high glucose-induced M1 macrophage switching to M2 via the VDR-PPAR gamma signaling pathway. Biomed. Res. Int. 2015, 2015, 157834. [CrossRef]

96. Adorini, L.; Giarratana, N.; Penna, G. Pharmacological induction of tolerogenic dendritic cells and regulatory T cells. Semin. Immunol. 2004, 16, 127-134. [CrossRef] [PubMed]

97. Adorini, L.; Penna, G.; Giarratana, N.; Uskokovic, M. Tolerogenic dendritic cells induced by vitamin $\mathrm{D}$ receptor ligands enhance regulatory $\mathrm{T}$ cell inhibiting allograft rejection and autoimmune diseases. J. Cell Biochem. 2003, 88, 227-233. [CrossRef] [PubMed]

98. Ferreira, G.B.; Vanherwegen, A.S.; Eelen, G.; Gutierrez, A.C.; Van Lommel, L.; Marchal, K.; Verlinden, L.; Verstuyf, A.; Noqueira, T.; Georgiadou, M.; et al. Vitamin D3 induces tolerance in human dendritic cells by activation of intracellular metabolic pathways. Cell Rep. 2015, 10, 711-725. [CrossRef]

99. Farias, A.S.; Spagnol, G.S.; Bordeaux-Rego, P.; Oliveira, C.O.; Fontana, A.G.; de Paula, R.F.; Santos, M.P.; Pradella, F.; Moraes, A.S.; Oliveira, E.C.; et al. Vitamin D3 induces IDO+ tolerogenic DCs and enhances Treg, reducing the severity of EAE. CNS Neurosci. Ther. 2013, 19, 269-277. [CrossRef] [PubMed] 
100. van der Aar, A.M.; Sibiryak, D.S.; Bakdash, G.; van Capel, T.M.; van der Kleij, H.P.; Opstelten, D.J.; Teunissen, M.B.; Kapsenberg, M.L.; de Jong, E.C. Vitamin D3 targets epidermal and dermal dendritic cells for induction of distinct regulatory T cells. J. Allergy Clin. Immunol. 2011, 127, 1532.e-1540.e. [CrossRef]

101. Gauzzi, M.C.; Purificato, C.; Donato, K.; Jin, Y.; Wang, L.; Daniel, K.C.; Maghazachi, A.A.; Belardelli, F.; Aldorini, L.; Gessani, S. Suppressive effect of 1alpha, 25-dihydroxyvitamin D3 on type I IFN-mediated monocyte differentiation into dendritic cells: Impairment of functional activities and chemotaxis. J. Immunol. 2005, 174, 270-276. [CrossRef] [PubMed]

102. Piemonti, L.; Monti, P.; Sironi, M.; Fraticelli, P.; Leone, B.E.; Dal Cin, E.; Allavena, P.; Di Carlo, V. Vitamin D3 affects differentiation, maturation, and function of human monocyte-derived dendritic cells. J. Immunol. 2000, 164, 4443-4451. [CrossRef] [PubMed]

103. Penna, G.; Adorini, L. 1 Alpha,25-dihydroxyvitamin D3 inhibits differentiation, maturation, activation, and survival of dendritic cells leading to impaired alloreactive T cell activation. J. Immunol. 2000, 164, 2405-2411. [CrossRef]

104. van Etten, E.; Mathieu, C. Immunoregulation by 1,25-dihydroxyvitamin D3: Basic concepts. J. Steroid. Biochem. Mol. Biol. 2005, 97, 93-101. [CrossRef]

105. Palmer, M.T.; Lee, Y.K.; Maynard, C.L.; Oliver, J.R.; Bikle, D.D.; Jetten, A.M.; Weaver, C.T. Lineage-specific effects of 1,25-dihydroxyvitamin D3 on the development of effector CD4 T cells. J. Biol. Chem. 2011, 286, 997-1004. [CrossRef]

106. Rubtsov, Y.P.; Rasmussen, J.P.; Chi, E.Y.; Fontenot, J.; Castelli, L.; Ye, X.; Treuting, P.; Siewe, L.; Roers, A.; Henderson, W.R., Jr.; et al. Regulatory T cell-derived interleukin-10 limits inflammation at environmental interfaces. Immunity 2008, 28, 546-558. [CrossRef] [PubMed]

107. Piantoni, S.; Andreoli, L.; Scarsi, M.; Zanola, A.; Dall'Ara, F.; Pizzorni, C.; Cutolo, M.; Airo, P.; Tincani, A. Phenotype modifications of T-cells and their shift toward a Th2 response in patients with systemic lupus erythematosus supplemented with different monthly regimens of vitamin D. Lupus 2015, 24, 490-498. [CrossRef] [PubMed]

108. Tian, Y.; Wang, C.; Ye, Z.; Xiao, X.; Kijlstra, A.; Yang, P. Effect of 1,25-dihy-droxyvitamin D3 on Th17 and Th1 response in patients with Behcet's disease. Invest. Ophthalmol. Vis. Sci. 2012, 53, 6434-6441. [CrossRef] [PubMed]

109. Colin, E.M.; Asmawidjaja, P.S.; van Hamburg, J.P.; Mus, A.M.; van Driel, M.; Hazes, J.M.; van Leeuwen, J.P.; Lubberts, E. 1,25-dihydroxyvitamin D3 modulates Th17 polarization and inter leukin-22 expression by memory T cells from patients with early rheumatoid arthritis. Arthritis Rheum. 2010, 62, 132-142. [CrossRef]

110. Jeffery, L.E.; Burke, F.; Mura, M.; Zheng, Y.; Qureshi, O.S.; Hewison, M.; Walker, L.S.; Lammas, D.A.; Raza, K.; Sansom, D.M. 1,25-Dihydroxyvitamin D3 and IL-2 combine to inhibit T cell production of inflammatory cytokines and promote development of regulatory T cells expressing CTLA-4 and FoxP3. J. Immunol. 2009, 183, 5458-5467. [CrossRef] [PubMed]

111. Lysandropoulos, A.P.; Jaquiery, E.; Jilek, S.; Pantaleo, G.; Schluep, M.; Du Pasquier, R.A. Vitamin D has a direct immunomodulatory effect on CD8+ T cells of patients with early multiple sclerosis and healthy control subjects. J. Neuroimmunol. 2011, 233, 240-244. [CrossRef] [PubMed]

112. Chen, J.; Bruce, D.; Cantorna, M.T. Vitamin D receptor expression controls proliferation of naive CD8+ T cells and development of CD8 mediated gastrointestinal inflammation. BMC Immunol. 2014, 15, 6. [CrossRef]

113. Heine, G.; Niesner, U.; Chang, H.D.; Steinmeyer, A.; Zugel, U.; Zuberbier, T.; Radbruch, A.; Worm, M. 1,25-dihydroxyvitamin D3 promotes IL-10 production in human B cells. Eur. J. Immunol. 2008, 38, 2210-2218. [CrossRef]

114. Chen, S.; Sims, G.P.; Chen, X.X.; Gu, Y.Y.; Chen, S.; Lipsky, P.E. Modulatory effects of 1,25-dihydroxyvitamin D3 on human B cell differentiation. J. Immunol. 2007, 179, 1634-1647. [CrossRef]

115. Lemire, J.M.; Adams, J.S.; Sakai, R.; Jordan, S.C. 1 alpha,25-dihydroxyvitamin D3 suppresses proliferation and immunoglobulin production by normal human peripheral blood mononuclear cells. J. Clin. Invest. 1984, 74, 657-661. [CrossRef]

116. Geldmeyer-Hilt, K.; Heine, G.; Hartmann, B.; Baumgrass, R.; Radbruch, A.; Worm, M. 1,25-dihydroxyvitamin D3 impairs NF-kappaB activation in human naive B cells. Biochem. Biophys. Res. Commun. 2011, 407, 699-702. [CrossRef] [PubMed]

117. Drozdenko, G.; Scheel, T.; Heine, G.; Baumgrass, R.; Worm, M. Impaired T cell activation and cytokine production by calcitriol-primed human B cells. Clin. Exp. Immunol. 2014, 178, 364-372. [CrossRef] [PubMed] 
118. Grammatiki, M.; Karras, S.; Kotsa, K. The role of vitamin D in the pathogenesis and treatment of diabetes mellitus: A narrative review. Hormones 2018, 1-12. [CrossRef] [PubMed]

119. Littorin, B.; Blom, P.; Scholin, A.; Arnqvist, H.J.; Blohmé, G.; Bolinder, J.; Ekbom-Schnell, A.; Eriksson, J.W.; Gudbjörnsdottir, S.; Nyström, L.; et al. Lower levels of plasma 25-hydroxyvitamin D among young adults at diagnosis of autoimmune type 1 diabetes compared with control subjects: Results from the nationwide diabetes incidence study in Sweden (DISS). Diabetologia 2006, 49, 2847-2852. [CrossRef] [PubMed]

120. Greer, R.M.; Portelli, S.L.; Hung, B.S.; Cleghorn, G.J.; McMahon, S.K.; Batch, J.A.; Conwell, L.S. Serum vitamin D levels are lower in Australian children and adolescence with type 1 diabetes than in children without diabetes. Pediatr. Diabetes 2013, 14, 31-41. [CrossRef] [PubMed]

121. Daga, R.A.; Laway, B.A.; Shah, Z.A.; Mir, S.A.; Kotwal, S.K.; Zargar, A.H. High prevalence of vitamin D deficiency among newly diagnosed youth-onset diabetes mellitus in north India. Arq. Bras. Endocrinol. Metabol. 2012, 56, 423-428. [CrossRef] [PubMed]

122. Federico, G.; Genoni, A.; Puggioni, A.; Saba, A.; Gallo, D.; Randazzo, E.; Salvatoni, A.; Toniolo, A. Vitamin D status, enterovirus infrction, and type 1 diabetes in Italian children/adolescents. Pediatr. Diabetes 2018, 19, 923-929. [CrossRef]

123. Bener, A.; Alsaied, A.; Al-Ali, M.; Al-Kubaisi, A.; Basha, B.; Abraham, A.; Guiter, G.; Mian, M. High prevalence of vitamin D deficiency in type 1 diabetes mellitus and healthy children. Acta Diabetol. 2009, 46, 183-189. [CrossRef]

124. Rasoul, M.A.; Al-Mahdi, M.; Al-Kandari, H.; Dhaunusi, G.S.; Haider, M.Z. Low serum vitamin D status is associated with high prevalence and early onset of type-1 diabetes mellitus in Kuwaiti children. BMC Pediatr. 2016, 16, 95. [CrossRef]

125. Janner, M.; Ballinari, P.; Mullis, P.E.; Flück, C.E. High prevalence of vitamin D deficiency in children and adolescence with type 1 diabetes. Swiss. Med. Wkly. 2010, 140, w13091. [CrossRef]

126. Reinert-Hartwall, L.; Honkanen, J.; Härkönen, T.; Ilonen, J.; Simell, O.; Peet, A.; Tillmann, V.; Lamberg-Allardt, C.; Virtanen, S.M.; Knip, M.; et al. No association between vitamin D and $\beta$-cell autoimmunity in Finnish and Estonian children. Diabetes Metab. Res. Rev. 2014, 30, 749-760. [CrossRef] [PubMed]

127. Sørensen, I.M.; Joner, G.; Jenum, P.A.; Eskild, A.; Torjesen, P.A.; Stene, L.C. Maternal serum levels of 25-hydroxy-vitamin D during pregnancy and risk of type 1 diabetes in the offspring. Diabetes 2012, 61, 175-178. [CrossRef] [PubMed]

128. Jacobsen, R.; Moldovan, M.; Vaag, A.A.; Hypponen, E.; Heitmann, B.L. Vitamin D fortification and seasonality of birth in type 1 diabetic cases: D-tect study. J. Dev. Orig. Health Dis. 2016, 7, 114-119. [CrossRef] [PubMed]

129. Miettinen, M.E.; Reinert, L.; Kinnunen, L.; Harjutsalo, V.; Koskela, P.; Surcel, H.M.; Lamberg-Allardt, C.; Tuomilehto, J. Serum 25-hydroxyvitamin D level during early pregnancy and type 1 diabetes risk in the offspring. Diabetologia 2012, 55, 1291-1294. [CrossRef] [PubMed]

130. Dong, J.Y.; Zhang, W.G.; Chen, J.J.; Zhang, Z.L.; Han, S.F.; Qin, L.Q. Vitamin D intake and risk of type 1 diabetes: A meta-analysis of observational studies. Nutrients 2013, 5, 3551-3562. [CrossRef] [PubMed]

131. Cadario, F.; Savastio, S.; Pagliardini, V.; Bagnati, M.; Vidali, M.; Cerutti, F.; Rabbone, I.; Fontana, F.; Lera, R.; De Donno, V.; Valori, A.; et al. Vitamin D levels at birth and risk of type 1 diabetes in childhood: A case-control study. Acta Diabetol. 2015, 52, 1077-1081. [CrossRef] [PubMed]

132. Zipitis, C.S.; Akobeng, A.K. Vitamin D supplementation in early childhood and risk of type 1 diabetes: A systematic review and meta-analysis. Arch. Dis. Child. 2008, 93, 512-517. [CrossRef] [PubMed]

133. Stene, L.C.; Joner, G.; Norwegian Childhood Diabetes Study Group. Use of cod liver oil during the first year of life is associated with lower risk of childhood-onset type 1 diabetes: A large, population-based, case-control study. Am. J. Clin. Nutr. 2003, 78, 1128-1134. [CrossRef]

134. Antico, A.; Tampoia, M.; Tozzoli, R.; Bizzaro, N. Can supplementation with vitamin D reduce the risk or modify the course of autoimmune diseases? A systematic review of the literature. Autoimmun. Rev. 2012, 12, 127-136. [CrossRef]

135. Hyppönen, E.; Läärä, E.; Reunanen, A.; Järvelin, M.R.; Virtanen, S.M. Intake of vitamin D and risk of type 1 diabetes: A birth-cohort study. Lancet 2001, 358, 1500-1503. [CrossRef]

136. Raab, J.; Giannopoulou, E.Z.; Schneider, S.; Warncke, K.; Krasmann, M.; Winkler, C.; Ziegler, A.G. Prevalence of vitamin D deficiency in pre-type 1 diabetes and its association with disease progression. Diabetologia 2014, 57, 902-908. [CrossRef] [PubMed] 
137. Mäkinen, M.; Mykkänen, J.; Koskinen, M.; Simell, V.; Veijola, R.; Hyöty, H.; Ilonen, J.; Knip, M.; Simell, O.; Toppari, J. Serum 25-hydroxyvitamin D concentrations in children progressing to autoimmunity and clinical type 1 diabetes. J. Clin. Endocrinol. Metab. 2016, 101, 723-729. [CrossRef] [PubMed]

138. Simpson, M.; Brady, H.; Yin, X.; Seifert, J.; Barriga, K.; Hoffman, M.; Bugawan, T.; Barón, A.E.; Sokol, R.J.; Eisenbarth, G.; et al. No association of vitamin D intake or 25-hydroxyvitamin D levels in childhood with risk of islet autoimmunity and type 1 diabetes: The diabetes autoimmunity study in the young (DAISY). Diabetologia 2011, 54, 2779-2788. [CrossRef] [PubMed]

139. Gorham, E.D.; Garland, C.F.; Burgi, A.A.; Mohr, S.B.; Zeng, K.; Hofflich, H.; Kim, J.J.; Ricordi, C. Lower prediagnostic serum 25-hydroxyvitamin D concentration is associated with higher risk of insulin-requiring diabetes: A nested case-control study. Diabetologia 2012, 55, 3224-3227. [CrossRef] [PubMed]

140. Munger, K.L.; Levin, L.I.; Massa, J.; Horst, R.; Orban, T.; Ascherio, A. Preclinical serum 25-hydroxyvitamin D levels and risk of type 1 diabetes in a cohort of US military personnel. Am. J. Epidemiol. 2013, 177, 411-419. [CrossRef] [PubMed]

141. Thrailkill, K.M.; Jo, C.H.; Cockrell, G.E.; Moreau, C.S.; Fowlkes, J.L. Enhanced excretion of Vitamin D binding protein in type 1 diabetes: A role in vitamin D deficiency? J. Clin. Edocrinol. Metab. 2011, 96, 142-149. [CrossRef] [PubMed]

142. Felício, K.M.; de Souza, A.C.C.B.; Neto, J.F.A.; de Melo, F.T.C.; Carvalho, C.T.; Arbage, T.P.; de Rider Brito, H.A.; Peixoto, A.S.; de Oliveira, A.F.; de Souza Resende, F.; et al. Glycemic variability and insulin needs in patients with type 1 diabetes mellitus supplemented with vitamin D: A pilot study using continuous glucose monitoring system. Curr. Diabetes Rev. 2018, 14, 395-403. [CrossRef] [PubMed]

143. Bogdanou, D.; Penna-Martinez, M.; Filmann, N.; Chung, T.L.; Moran-Auth, Y.; Wehrle, J.; Cappel, C.; Huenecke, S.; Herrmann, E.; Koehl, U.; et al. T-lymphocyte and glycemic status after vitamin D treatment in type 1 diabetes: A randomized controlled trial with sequential crossover. Diabetes Metabol. Res. Rev. 2016, 33, e2865. [CrossRef] [PubMed]

144. Li, X.; Liao, L.; Yan, X.; Huang, G.; Lin, J.; Lei, M.; Wang, X.; Zhou, Z. Protective effects of 1-alpha-hydroxyvitamin D3 on residual beta-cell function in patients with adult-onset latent autoimmune diabetes (LADA). Diabetes Metab. Res. Rev. 2009, 25, 411-416. [CrossRef]

145. Ataie-Jafari, A.; Loke, S.C.; Rahmat, A.B.; Larijani, B.; Abbasi, F.; Leow, M.K.; Yassin, Z. A randomized placebo-controlled trial of alphacalcidol on the preservation of beta cell function in children with recent onset type 1 diabetes. Clin. Nutr. 2013, 32, 911-917. [CrossRef]

146. Pitocco, D.; Crino, A.; di Stasio, E.; Manfrini, S.; Guglielmi, C.; Spera, S.; Anguissola, G.B.; Visalli, N.; Suraci, C.; Matteoli, M.C.; et al. The effects of calcitriol and nicotinamide on residual pancreatic beta-cell function in patients with recent-onset Type 1 diabetes (IMDIAB XI). Diabetes Med. 2006, 23, 920-923. [CrossRef] [PubMed]

147. Mishra, A.; Dayal, D.; Sachdeva, N.; Attri, S.V. Effect of 6-months' Vitamin D supplementation on residual beta cell function in children with type 1 diabetes: A case control interventional study. J. Pediatr. Endocrinol. Metab. 2016, 29, 395-400. [CrossRef] [PubMed]

148. Federico, G.; Focosi, D.; Marchi, B.; Randazzo, E.; De Donno, M.; Vierucci, F.; Bugliani, M.; Campi, F.; Scatena, F.; Saggese, G.; et al. Administering 25-hydroxyvitamin D3 in Vitamin D-deficient young type 1A diabetic patients reduces reactivity against islet autoantigens. Clin. Nutr. 2014, 33, 1153-1156. [CrossRef] [PubMed]

149. Giri, D.; Pintus, D.; Burnside, G.; Ghatak, A.; Mehta, F.; Paul, P.; Senniappan, S. Treating vitamin D deficiency in children with type 1 diabetes could improve their glycaemic control. BMC Res. Notes 2017, 10, 465. [CrossRef] [PubMed]

150. Dehkordi, E.H.; Dehkordi, V.H.; Fatemi, S.M.R.; Zolfaghari, M. Effect of vitamin D supplement therapy on HbA1C and IGF-1 levels in children with type 1 diabetes mellitus and vitamin D deficiency. Electron. J. Gen. Med. 2018, 15, em69. [CrossRef]

151. Deda, L.; Yeshayahu, Y.; Sud, S.; Cuerden, M.; Cherney, D.Z.; Sochett, E.B.; Mahmud, F.H. Improvements in pheripherial vascular function with vitamin $\mathrm{D}$ treatment in deficient adolescents with type 1 diabetes. Pediatr. Diabetes 2018, 19, 457-463. [CrossRef] [PubMed] 
152. Gabbay, M.A.; Sato, M.N.; Finazzo, C.; Duarte, A.J.; Dib, S.A. Effect of cholecalciferol as adjunctive therapy with insulin on protective immunologic profile and decline of residual beta-cell function in new-onset type 1 diabetes mellitus. Arch. Pediatr. Adolesc. Med. 2012, 166, 601-607. [CrossRef]

153. Treiber, G.; Prietl, B.; Fröhlich-Reiterer, E.; Lechner, E.; Ribitsch, A.; Fritsch, M.; Rami-Merhar, B.; Steigleder-Schweiger, C.; Graninger, W.; Borkenstein, M.; et al. Cholecalciferol supplementation improves suppressive capacity of regulatory T-cells in young patients with new-onset type 1 diabetes mellitus-A randomized clinical trial. Clin. Immunol. 2015, 161, 217-224. [CrossRef]

154. Bizzarri, C.; Pitocco, D.; Napoli, N.; Di Stasio, E.; Maggi, D.; Manfrini, S.; Suraci, C.; Cavallo, M.G.; Cappa, M.; Ghirlanda, G.; et al. No protective effect of calcitriol on beta-cell function in recent-onset type 1 diabetes: The IMDIAB XIII trial. Diabetes Care 2010, 33, 1962-1963. [CrossRef]

155. Walter, M.; Kaupper, T.; Adler, K.; Foersch, J.; Bonifacio, E.; Ziegler, A.G. No effect of the 1alpha,25-dihydroxyvitamin D3 on beta-cell residual function and insulin requirement in adults with new-onset type 1 diabetes. Diabetes Care 2010, 33, 1443-1448. [CrossRef]

156. Perchard, R.; Megee, L.; Whatmore, A.; Ivison, F.; Murray, P.; Stevens, A.; Maghal, M.Z.; Ehtisham, S.; Campbell, J.; Ainworth, S.; et al. A pilot interventional study to evaluate the impact of cholecalciferol treatment on HbA1C in type 1 diabetes. Endocr. Connect. 2017, 6, 225-231. [CrossRef] [PubMed]

(C) 2018 by the authors. Licensee MDPI, Basel, Switzerland. This article is an open access article distributed under the terms and conditions of the Creative Commons Attribution (CC BY) license (http:/ / creativecommons.org/licenses/by/4.0/). 